\title{
Bovine trophectoderm cells induced from bovine fibroblasts with induced pluripotent stem cell reprogramming factors
}

\author{
Neil C. Talbot ${ }^{1}$ (i) | Wendy O. Sparks ${ }^{1}$ | Caitlin E. Phillips ${ }^{1}$ | Alan D. Ealy ${ }^{2}$ \\ Anne M. Powell $^{1}$ | Thomas J. Caperna ${ }^{1}$ | Wesley M. Garrett ${ }^{1}$ | \\ David M. Donovan $^{1}$ | Le Ann Blomberg ${ }^{1}$
}

1 U.S. Department of Agriculture, Agricultural Research Service, Animal Biosciences and Biotechnology Laboratory, Beltsville, Maryland

2 Department of Animal and Poultry Sciences,

Virginia Tech, Blacksburg, Virginia

\section{Correspondence}

Neil C. Talbot, USDA-ARS, ANRI, Animal

Biosciences and Biotechnology Laboratory, Bldg. 200, Rm. 13, BARC-East, 10300 Baltimore Blvd. Beltsville, MD 20705.

E-mail: neil.talbot@ars.usda.gov
Thirteen independent induced bovine trophectroderm (iBT) cell lines were established by reprogramming bovine fetal liver-derived fibroblasts after viral-vector transduction with either six or eight factors, including POU5F1 (OCT4), KLF4, SOX2, MYC, NANOG, LIN28, SV40 large T antigen, and hTERT. Light- and electron-microscopy analysis showed that the iBT cells had epithelial cell morphology typical of bovine trophectoderm cells. Reverse-transcription-PCR assays indicated that all of the cell lines expressed interferon-tau (IFNT) at passages 1 or 2. At later passages ( $\geq$ passage 8 ), however, immunoblot and antiviral activity assays revealed that more than half of the iBT cell lines had stopped expressing IFNT. Messenger RNAs specific to trophectoderm differentiation and function were found in the iBT cell lines, and 2-dimensionalgel analysis for cellular proteins showed an expression pattern similar to that of trophectoderm cell lines derived from bovine blastocysts. Integration of some of the human reprogramming factors, including POU5F1, KLF4, SOX2, MYC, NANOG, and LIN28, were detected by PCR, but their transcription was mostly absent in the iBT cell lines. Gene expression assessment of endogenous bovine reprogramming factor orthologs revealed endogenous bLIN28 and bMYC transcripts in all; $b S O X 2$ and $b N A N O G$ in none; and bKLF4 and bPOU5F1 in less than half of the iBT cell lines. These results demonstrate that bovine trophectoderm can be induced via reprogramming factor expression from bovine liver-derived fibroblasts, although other fibroblast populations-e.g., derived from fetal thigh tissue-may produce similar results, albeit at lower frequencies.

\section{KEYWORDS}

bovine, cell culture, induced, iPSC, reprogramming, trophectoderm
Abbreviations: AP, alkaline phosphatase; CT-1, bovine blastocyst-derived trophectoderm cell line; DMEM, Dulbecco's Modified Eagle Medium; ESC, embryonic stem cells; iBT, induced bovine trophectoderm cell; iPSC, induced pluripotent stem cell; JF, Jersey fetal; OSKM[NL], OCT4-SOX2-KLF4-MYC[NANOG-LIN28]; P\#, passage number; STO, Sandoz inbred strain thioguanine- and ouabain-resistance.

Mention of trade name, proprietary product or vendor does not constitute a guarantee or warranty of the product by the U.S. Department of Agriculture or imply its approval to the exclusion of other products or vendors that also may be suitable.

\section{1 | INTRODUCTION}

The "reprogramming" of somatic cells by specific transgene expression to convert them into induced pluripotent stem cells (iPSCs), or "directly" into specific alternative types of somatic cells, is now well demonstrated. The creation of mouse iPSCs from mouse fibroblasts via the ectopic expression of four pluripotency-related transcription factors-POU domain, class 5, transcription factor 1 (POU5F1, a.k.a. OCT4), SRY (sex determining region Y)-box 2 (SOX2), Kruppel-like transcription factor 4 (KLF4), and the $\mathrm{v}$-Myc avian myelocytomatosis viral oncogene cellular homolog (MYC), altogether abbreviated OSKM -was first described in 2006 (Takahashi \& Yamanaka, 2006). Soon thereafter came the reported creation of human iPSCs through the use 
of these and other so-called reprogramming factors, and, more importantly, the ability of mouse iPSCs to give rise to chimeric embryos with germ-line transmission in the resulting mice (Okita, Ichisaka, \& Yamanaka, 2007; Takahashi et al., 2007; Wernig et al., 2007; Yu et al., 2007).

Publications detailing the generation of putative iPSC from various ungulate species-including pig (Ezashi et al., 2009; Telugu et al., 2011; West et al., 2010, 2011; Wu et al., 2009), horse (Nagy et al., 2011), goat (Ren et al., 2011; Sandmaier et al., 2015; Song et al., 2013), sheep (Bao et al., 2011; Li, Cang, Lee, Zhang, \& Liu, 2011), and cattle (Cao et al., 2012; Han et al., 2011; Sumer et al., 2011)-appeared soon after the reports for mouse and human cells, with several more papers describing bovine iPSC generation published recently by independent laboratories (Cravero et al., 2015; Heo et al., 2015; Kawaguchi et al., 2015; Nong et al., 2015; Talluri et al., 2015). Reprogramming the somatic cells of some ungulate species required factors in addition to OSKM, such as LIN28, NANOG, Simian Vacuolating Virus 40 T-antigen (a.k.a. SV40 large T antigen; SV40TAg), and/or human telomerase reverse transcriptase (hTERT), to achieve induction of embryonic stem cell (ESC)-like properties (Bao et al., 2011; Han et al., 2011; Nong et al., 2015; Sumer et al., 2011; Talluri et al., 2015).

Reports describing a failure to fully reprogram ungulate fibroblasts using OSKM plus other factors are rare. Thomson et al. described OSKM-mediated reprogramming of pig fibroblasts that yielded iPSClike cells, which were apparently not fully reprogrammed (Thomson et al., 2012). Despite the iPSC-like cells being positive for alkaline phosphatase (AP), a universal marker of pluripotency in embryonal carcinoma cells, ESC, and pig, sheep, and bovine epiblast cells (Nicolas et al., 1976; Talbot, Powell, \& Rexroad, 1995; Talbot, Rexroad, Pursel, \& Powell, 1993; Wobus, Holzhausen, Jäkel, \& Schöneich, 1984), in vitro testing of these pig iPSC-like cell lines only demonstrated their differentiation into cells expressing neuronal markers or cells positive for alpha-fetoprotein expression, which could be indicative of either yolk-sac endoderm cells or hepatocytes (Thomson et al., 2012). Indeed, injection of these porcine iPSC-like cells into immunocompromized mice, which tests for teratoma formation, resulted in tumors containing tissue of a "predominantly glandular phenotype" (Thomson et al., 2012). Another recent report documented the apparently incomplete OSKM-mediated reprogramming of goat fibroblasts into goat iPSC-like cells that differentiated into neuronal cells, yolk-sac endoderm, and trophectoderm (Sandmaier et al., 2015).

Induction of other cell types besides ESC-like cells was noted during OSKM-mediated reprogramming of pig fibroblasts to putative pig iPSCs (Ezashi et al., 2009). Ezashi et al. characterized the nature of this commonly occurring, non-ESC-like reprogrammed cell type, and showed that it was indistinguishable from the trophectoderm cells of the pig embryo (Ezashi, Matsuyama, Telugu, \& Roberts 2011). These cells, designated as pig induced trophoblast (iTR), were flat, epithelial cells connected to one another by tight-junctions and associated desmosomes. Their epithelial nature and tight-junction attribute was evidenced by the cells' colony-outgrowths forming domes indicative of the transport of culture fluid basolaterally underneath the cell monolayer. These pig iTR cells expressed several developmental and differentiation genes associated with trophectoderm, including cytokeratin 7 (KRT7), GATA2, PPARG, MSX2, DLX3, HAND1, GCM1, CDX2, ID2, ELF5, TCFAP2C, and TEAD4. Furthermore, the cells expressed trophectoderm-related functional genes of secreted proteins (i.e., PAG6 and PAG10), steroid synthesis (HSD17B1, CYP11A1, and STAR), mediators of inflammation (IFNG and IL1B) and prostaglandin synthesis (PTGES, COX1, and COX2). Thus, porcine fibroblasts clearly could be reprogrammed into cell types other than pluripotent cells by ectopic expression of OSKM-in this case, into extraembryonic trophectoderm cells.

Outlined in this report is our attempt to create bovine iPSC, as previously reported by others (Cao et al., 2012; Cravero et al., 2015; Han et al., 2011; Kawaguchi et al., 2015; Nong et al., 2015; Sumer et al., 2011; Talluri et al., 2015), using similar reprogramming factors, vectors, and culture methods. While bovine iPSC-like cells were produced in our experiments, these reprogrammed cells did not express high levels of AP. A second epithelial cell type was observed in some of the reprogramming experiments, many of which were AP-positive but did not resemble iPSCs in morphology. Several of these non-iPSC-like cells were independently colony-cloned and propagated in long-term, continuous culture as cell lines. Their characterization, presented herein, demonstrated a phenotype indistinguishable from bovine trophectoderm cell lines previously isolated from bovine blastocysts. We discuss possible reasons for our inability to replicate the results of others in deriving bovine iPSCs, and for the occurrence of trophectoderm lineages in our bovine cellreprogramming experiments.

\section{2 | RESULTS}

\section{1 | Induction of trophectoderm following transduction of bovine fetal fibroblasts with viral vectors of reprogramming factors}

Two separate experiments were conducted in which bovine cell lines from various tissues and from two separate fetuses (JF2 and JF3) were transduced with either a combination of six (OSKM + LIN28 and NANOG [LN]) or eight (OSKMLN + SV4OTAg and hTERT) reprogramming factors. Trophectoderm-like colonies began to appear among the transduced cells after a week in culture. Several reprogramming factor-induced colonies, whose cell and colony morphology were "ESC-like," were also observed, but these were invariably negative for AP activity, so their characterization was not pursued further.

The JF3 liver-derived fibroblasts produced the greatest number of trophectoderm-like colonies (Figure 1). JF3 liver-derived fibroblasts produced numerous colonies, whereas the other bovine fetal fibroblasts, derived from fetal thigh tissue, and endothelium-like cells, derived from Wharton's jelly or amniotic fluid, produced few or no such colonies after 3 weeks of culture. For example, the 6-factor induction of JF3 liver-derived fibroblasts gave 14 trophectoderm-like colonies after 30 days of culture, whereas the same induction paradigm of JF3 Wharton's jelly-derived and amniotic fluid-derived cells resulted in only one or no induced colonies, respectively. JF2 cells 


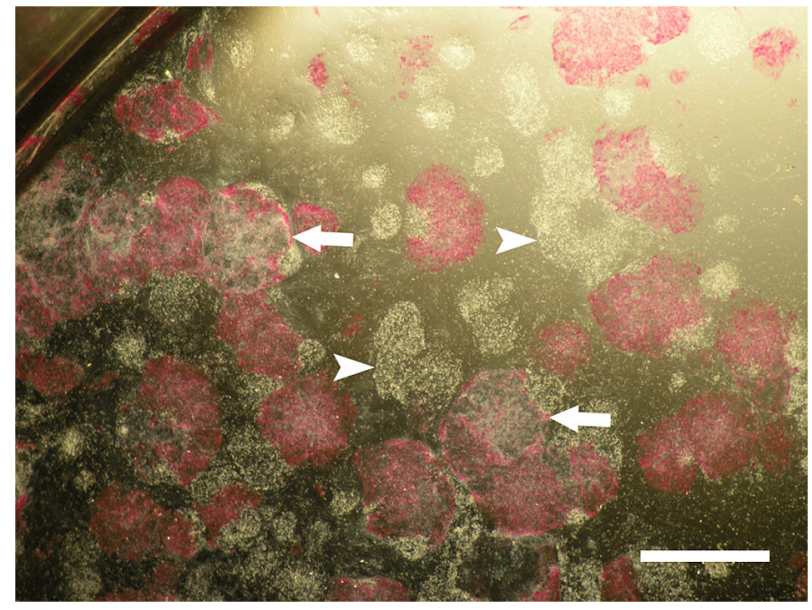

FIGURE 1 Low-magnification light micrograph of primary colonies of bovine trophectoderm induced from bovine fibroblasts.

Dissection-scope image of primary reprogramming factor-induced colonies stained for AP activity (red color). Arrows indicate AP-positive colonies with dome formation that is indicative of basolateral fluid transport. Arrowheads indicate AP-negative colonies. Scale bar, $10 \mathrm{~mm}$

derived from the liver, bone marrow, thigh tissue, and Wharton's jelly all failed to produce any trophectoderm-like or ESC-like colonies after transduction with either six or eight reprogramming factors. Comparing JF3 liver-derived fibroblasts to JF2 Wharton's jelly derived endothelium-like cells, the 8-factor induction paradigm resulted in a total of 125 trophectoderm-like colonies in the two primary induction plates of the JF3 liver-derived fibroblasts by Day 17 of culture, whereas the JF2 Wharton's Jelly-derived cells produced no colonies of any kind after 4 weeks of culture.

Fourteen independent colony isolations of trophectoderm-like cells from the JF3 fibroblast transductions were performed from the six- and eight-factor experiments to establish induced bovine trophectoderm-like (iBT) cell lines, and each colony was expanded to cultures of millions of cells on STO (Sandoz inbred strain, thioguanine- and ouabain-resistance) feeder cells in 10\% Dulbecco's Modified Eagle Medium (DMEM), as previously described for bovine embryo-derived trophectoderm cell lines (Talbot et al., 2000). Thirteen independent $\mathrm{iBT}$ cell lines were established from the 14 colonycloning isolations. The remaining cells in the primary culture plates were stained for AP activity, revealing that most of the trophectoderm-like colonies were AP-positive (Figure 1).

At passage 1 (P1), and subsequent secondary passages on STO feeder cells, the iBT cell lines displayed the typical morphology of bovine trophectoderm cells: the cells grow as tightly knit, epithelial monolayers with the boundary of their expanding colonies pushing many of the feeder cells out of their path (Figure 2) (Talbot et al., 2000). The iBT cell lines lost their AP activity after secondary culture began (not shown). As observed in some of the primary colonies (Figure 1), the expansion of secondary-culture iBT colonies to several thousands of cells resulted in their dome formation due to the basolateral transport of cell culture medium underneath the growing monolayer of cells. The morphology of the iBT cells was typical of bovine trophectoderm: irregularly cuboidal in shape, with a relatively granular

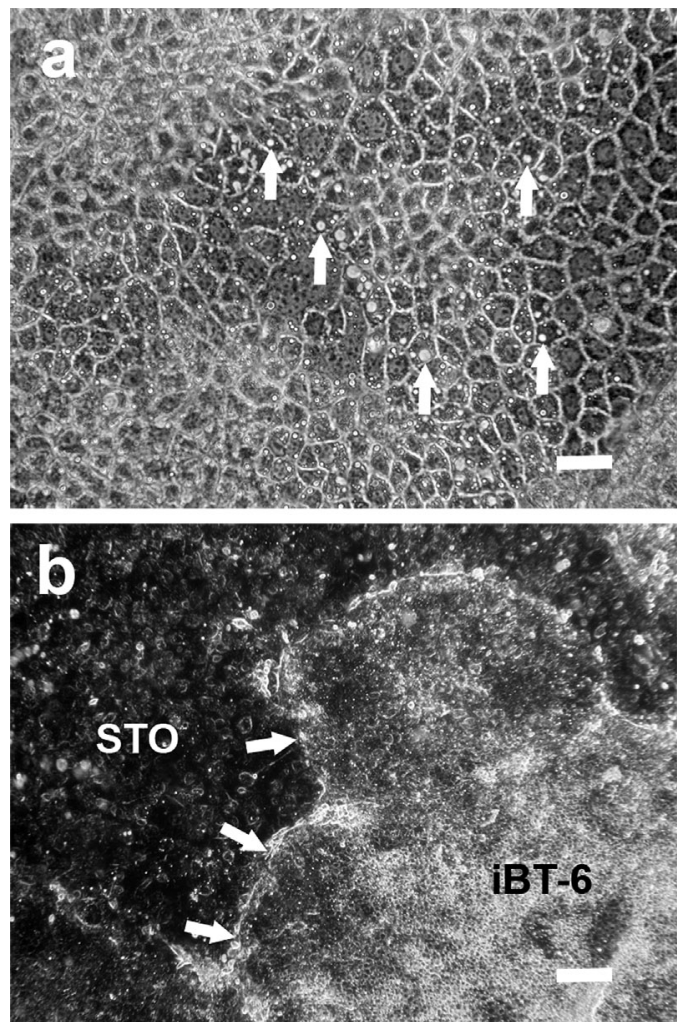

FIGURE 2 Light micrographs of iBT- 6 cells cultured on STO feeder cells at passage 11. a, Phase-contrast micrograph showing the cells' roughly cuboidal shape, granular cytoplasm, and occasional prominent lipid droplets (arrows). Scale bar, $25 \mu \mathrm{m}$. b, Pseudodark-field micrograph showing the coalescing colony outgrowths of recently passaged cells as they grow out across the STO feeder layer. Arrows indicate the iBT-6 monolayer boundary with the STO feeder cells. Scale bar, $100 \mu \mathrm{m}$

cytoplasm and visible lipid droplets in their cytoplasm (Figure 2). Transmission electron microscopy analysis of cell line iBT-7 showed the cell monolayer to be a polarized epithelium with abundant microvilli on the apical surface of the cells (Figure 3a) and lateral cellcell junctions resembling tight junctions, with their associated desmosomes holding the cells together (Figure $3 \mathrm{~b}$ ). One iBT-7 cell that we observed appeared binucleate within the monolayer (Figure 3a), but this could be an artifact of sectioning since the nuclei could be crescent-shaped, giving the impression of a cell with two nuclei, and its neighbor contained a prominent lipid vacuole (Figure 3a); otherwise, mitochondria with flat cristae, Golgi complexes, rough, and smooth endoplasmic reticulum, and free polysomes were well represented in the iBT-7 cells (not shown). No basement membrane was evident on the basal aspect of the cells (not shown), in agreement with previous ultrastructure inspections of STO co-cultured trophectoderm cells derived from bovine blastocysts (Talbot et al., 2000).

\subsection{Interferon-tau antiviral activity assay and protein expression in iBT cell lines}

Interferon-tau (IFNT) antiviral activity was assessed in conditioned medium of the iBT cell lines (Table 1); the CT-1 bovine trophectoderm 


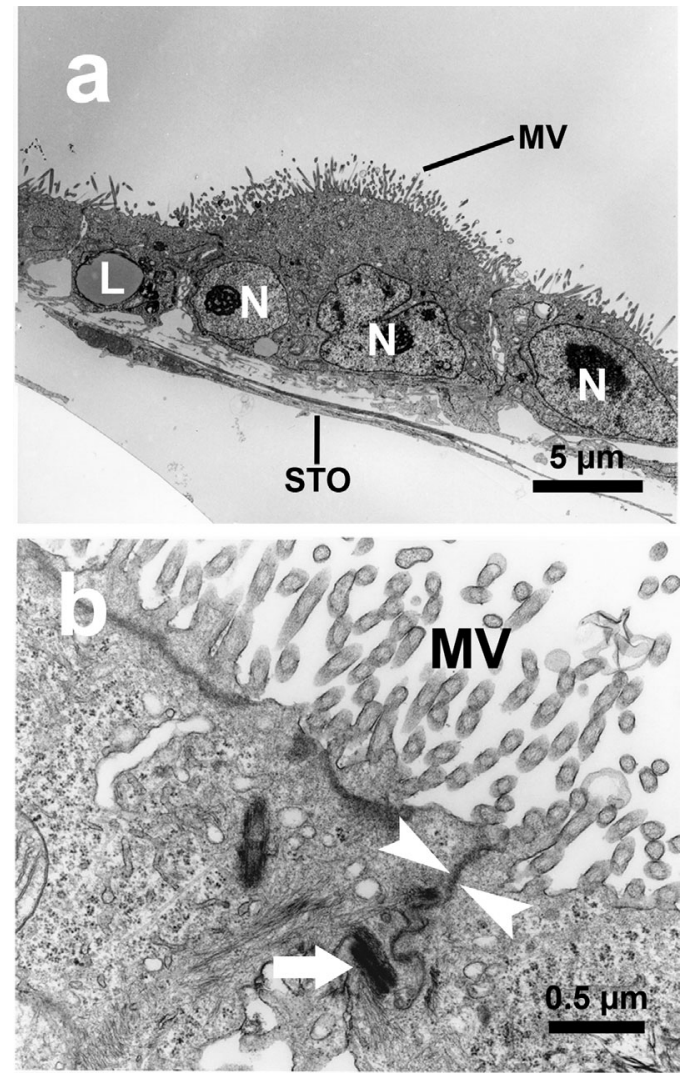

FIGURE 3 Transmission-electron micrographs of iBT-7 cells at passage 12 , from a nearly confluent monolayer of the cells. a, Lowmagnification, cross-section. Scale bar, $5 \mu \mathrm{m}$. b, Detailed, highmagnification view of the apical surface. Arrowheads indicate a tight junction between the iBT-7 cells; the arrow indicates the neighboring desmosome with its associated keratin microfilaments. Scale bar, $0.5 \mu \mathrm{m}$. L, lipid vacuole; MV, microvilli; N, nucleus

cell line, established from an in vitro-fertilized and cultured bovine blastocyst (Talbot et al., 2000), acted as a positive control. Assessment of the conditioned medium from the STO feeder cells alone, which all the iBT cell lines and the CT-1 cells are grown on, did not contribute to the measured IFNT antiviral activity (Table 1B). All of the iBT cell lines, however, showed some IFNT activity at an early passage (P2) (Table 1A), although some progressively lost IFNT expression with increasing passages (e.g., iBT-1, -7, -9, and -11) (Table 1B). While the levels of IFNT in the conditioned medium may reflect relative quantitative secretion of IFNT by the different iBT cell lines in some cases, such conclusions cannot be drawn from the data presented (Table 1 ) since the cultures were assayed at different levels of confluency, total cell number, and after varying amounts of passage in secondary culture.

The secretion of IFNT by the iBT cell lines was also assessed by Western blot. The proteins present in serum-free conditioned medium harvested from several of the iBT cell lines, CT-1 cells, and STO feeder cells alone were probed with a polyclonal anti-IFNT antibody. This antibody reacted with several proteins of $\sim 23 \mathrm{kDa}$, which is the appropriate size for differentially glycosylated IFNT (Figure 4a) (Talbot et al., 2000). Serum-free conditioned medium from STO feeder cells alone again showed that the STO cells were not producing the protein
TABLE 1 Interferon-tau anti-viral activity in conditioned medium of iBT cell lines versus blastocyst-derived trophectoderm cell line, CT-1

\begin{tabular}{|ll|}
\hline Sample & International antiviral units/ml \\
\hline iBT-1 (P2) & 1114 \\
\hline iBT-2 (P2) & 3334 \\
\hline iBT-3 (P2) & 609 \\
\hline iBT-4 (P2) & 609 \\
\hline iBT-5 (P2) & 45 \\
\hline iBT-6 (P2) & 626 \\
\hline iBT-7 (P2) & 4114 \\
\hline CT-1 (P2) & 64146 \\
\hline B & \\
\hline CT-1 (P34) & 3333 \\
\hline CT-1 (P30) & 1924 \\
\hline CT-1 (P32) & 1924 \\
\hline iBT-1 (P15) & 0 \\
\hline iBT-7 (P27) & 0 \\
\hline iBT-6 (P19) & 1924 \\
\hline iBT-6 (P22) & 1924 \\
\hline iBT-11 (P2) & 281 \\
\hline iBT-11 (P8) & 0 \\
\hline iBT-9 (P2) & 213 \\
\hline iBT-9 (P8) & 0 \\
\hline iBT-10 (P2) & 123 \\
\hline
\end{tabular}

detected by the anti-IFNT antibody (Figure 4a, lane 1). The CT-1 conditioned medium produced the most robust reaction with the antibody (Figure 4a, lanes 2 and 9), but as explained above, this abundance depended on the confluence and density of the cells at the time that the conditioned medium was collected. Cell lines iBT-9 and iBT-11, both assayed at passage 6 (Figure 4a, lanes 4 and 6 , respectively), did not produce any significant amount of IFNT, in agreement with the IFNT activity assay (Table 1B). The iBT-10 conditioned medium (Figures 4a, lane 5) showed a relatively weak anti-IFNT reactivity that probably reflected the relatively poor growth of this particular cell line at this passage. Four of the iBT cell linesiBT-6, iBT-10, iBT-12, and iBT-13-were assessed at both an early and later passages by Western blot (over nearly 9 months of continuous culture, at passages $\mathrm{P} 38, \mathrm{P} 19, \mathrm{P} 21$, and $\mathrm{P} 26$, respectively), revealing that IFNT secretion was maintained by these cell lines after extensive passaging (Figure 4b). Serum-free conditioned medium from the parental bovine liver-derived fibroblasts (JF3 fibroblast cell line) was also assessed with the anti-IFNT antibody, and showed no reaction (Figure 4b, lane 7). 

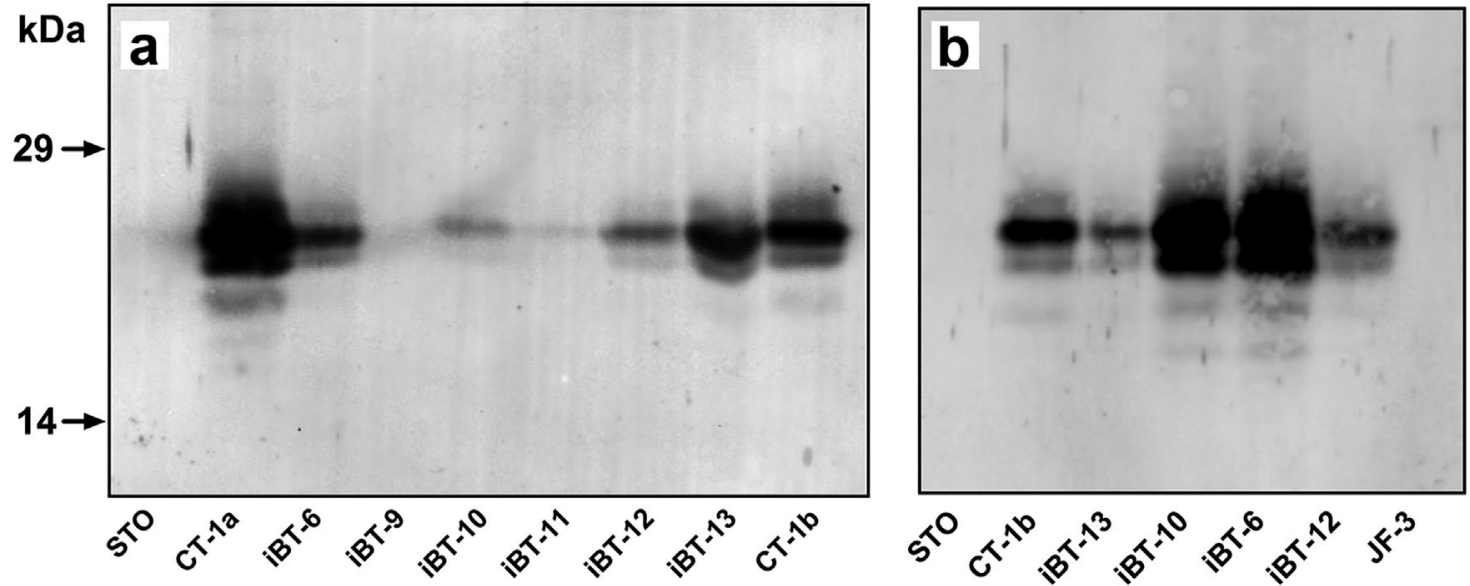

FIGURE 4 Immunoblot analysis for IFNT secretion by randomly selected iBT cell lines and the CT-1 bovine trophectoderm cell line. Neat, 48-hr serum-free conditioned media from various cell lines, as indicated, were probed with anti-bovine IFNT antibody. STO, feeder cells only (negative control). CT-1a (P32) and CT-1b (P34) indicate independent collections of CT-1 medium (positive control). JF3, Jersey fetus-3 liverderived fibroblasts used to create iBT cell lines by reprogramming-factor induction. Passages of the iBT cell lines were as follows: iBT-6 (P22 in a; P38 in b), iBT-9 (P6), iBT-10 (P8 in a; P19 in b), iBT-11 (P6), iBT-12 (P7 in a; P21 in b), iBT-13 (P8 in a; 26 in b), and JF3 fibroblasts (P2)

\section{3 | Two-dimensional-gel analysis of iBT cell line proteins}

Expression of the most abundant cellular proteins was assessed by twodimensional gel electrophoresis of the crude (i.e., unfractionated) cell lysates of some of the iBT cell lines (Figure 5). This approach revealed a protein profile similar to previously analyzed bovine trophectoderm cell lines derived from in vitro-matured, fertilized, and cultured blastocysts ("FT" lines) and to lines derived from in vivo-produced blastocysts ("VIVOT" lines) (Talbot, Powell, Camp, \& Ealy, 2007). The gels of iBT-2, FT19-1, and VIVOT-199 cell lines are representative from each group (Figure 5). Small differences in the expression of some proteins between iBT cell lines were evident, but none (with exception of two serum proteins; see below) were consistently differentially expressed, as assessed by red/green gel image overlays performed in Adobe Photoshop by false coloring. Several proteins that were possibly differentially expressed between the iBT cell lines versus FT and VIVOT cell lines were noted and identified by tandem mass spectrometry (Figure 5). Among the nine proteins selected for identification, three were previously reported as enriched in trophectoderm tissue, including galectin-3, glutathione $S$-transferase-pi, and the enzyme 2-oxo-4-hydroxy-4-carboxy-5-ureidoimidazoline decarboxylase (Figure 5, spot \#6), which is important in the production of allantoin (Cendron et al., 2007).

Two consistent and prominent differences in protein spots were found comparing the proteins of iBT cells to those of FT and VIVOT cells (circled in Figure 5); however, both proteins were identified as bovine serum proteins-albumin and alpha-2-HS glycoprotein (fetuinA). This differential expression may be an artifact of the culture conditions since these early secondary-passage iBT cells were maintained in iPSC medium; indeed, culturing the iBT-6 cell line in $10 \%$ fetal bovine serum in DMEM instead of iPSC medium, which contained $7.5 \%$ fetal bovine serum and $10 \%$ knockout serum replacement, resulted in the disappearance of the albumin and fetuin spots in the 2-dimensional gels of the crude iBT-6 lysate (not shown).
The FT19-1 and VIVOT-199 lines were cultured in 10\% fetal bovine serum in DMEM prior to analysis, so this difference may be an artifact resulting from the inability to remove all of the serum-proteins bound to the cells by simple washing of the cell monolayers with serum-free medium prior to extraction with the urea/thiourea lysis buffer. The presumptive identity of many of the remaining protein spots can be ascertained by consulting our previously published two-dimensional gel analysis of bovine trophectoderm cell lines (Talbot, Powell, Caperna, \& Garrett, 2010).

\section{4 | Comparative gene expression of trophectoderm-related genes in iBT cell lines}

The expression of several trophectoderm marker genes was assessed in select $\mathrm{iBT}$ cell lines by reverse-transcription PCR, and compared to the JF3 bovine liver-derived fibroblasts, from which the iBT cells were derived; to the CT-1 bovine trophectoderm cell line; and to STO feeder cells alone (Figure 6 and Table 4). The trophectoderm-related genes included ASCL2, CDX2, ELF5, ETS2, GATA2, GATA3, IFNT, SFN, and VIM. Non-trophectoderm-specific genes were also assessed, including $A L B$ and two ubiquitously expressed genes, ATCB and GAPDH. Like the CT-1 cell line, all the iBT cell lines assayed (iBT-1, -3, -7, -9, -11, and -13) expressed trophectoderm-associated genes-although the iBT-1, -3 , and -9 cell lines were negative for IFNT expression (Figure 6). The IFNT primers surprisingly produced an amplicon of the appropriate size from the JF3 fibroblast RNA sample (Figure 6; top row, left- and rightmost lanes), which is not consistent with the IFNT immunoblot analysis (above) (Figure 4b). JF3 cells were also positive for ETS2, GATA2, GATA3, VIM, ACTB, and GAPDH. VIM and GAPDH were the only transcripts detected in STO cells alone, indicating that these feeder cells likely did not interfere with the assessment of trophectodermrelated gene expression in the iBT cells lines.

The relatively low expression of IFNT by the JF3 fibroblast was examined further using several other IFNT primers sets, which gave 

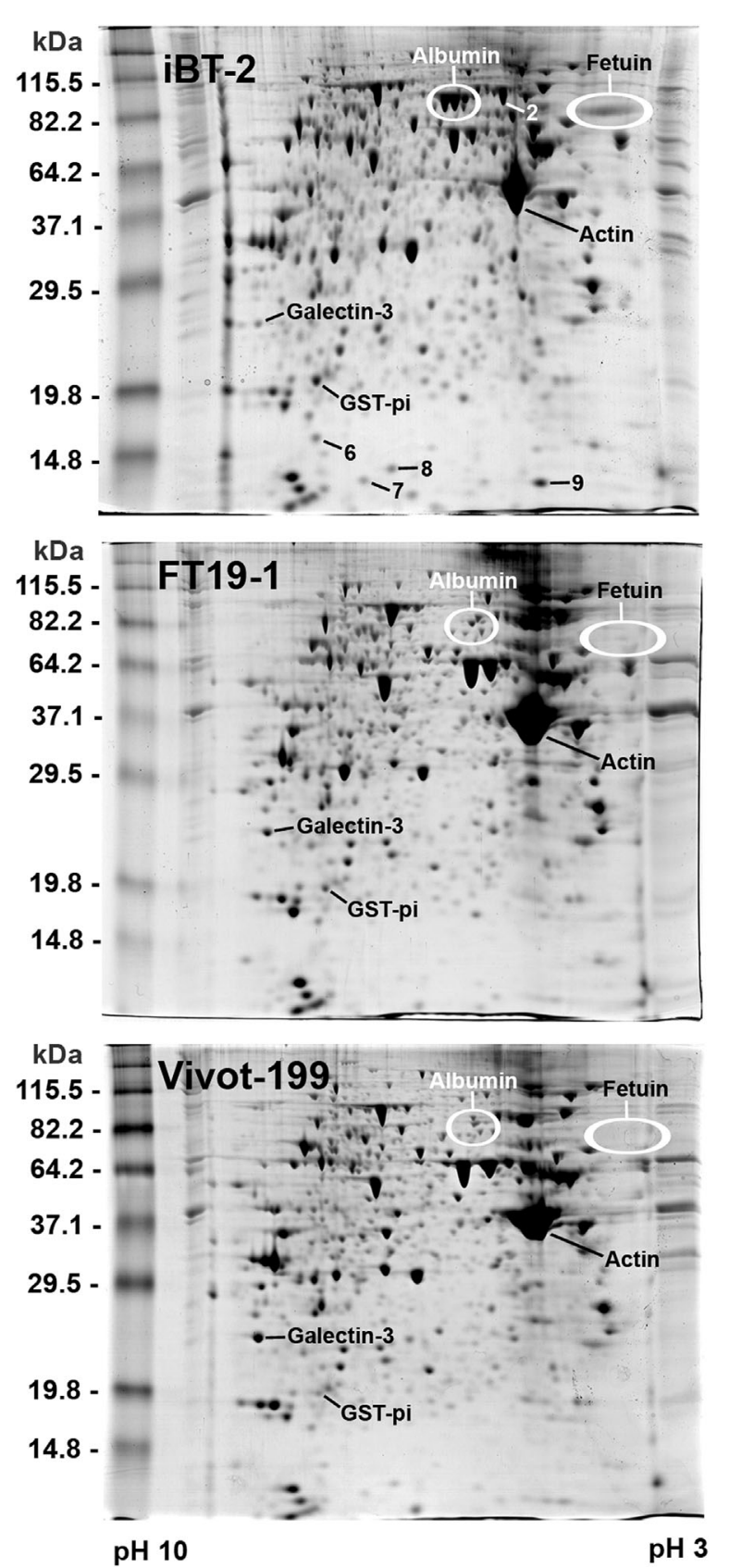

FIGURE 5 Two-dimensional gel-electrophoresis analysis of the abundant cell proteins of line iBT-2 (P11) compared to the in vitroproduced bovine blastocyst-derived cell line, FT19-1 (P2), and the in vivo-produced bovine blastocyst-derived cell line, VIVOT-199 (P11). Circled proteins, identified as albumin and fetuin, were artifacts resulting from the culture of the iBT- 2 cell line in medium containing both fetal bovine serum $(7.5 \% \mathrm{v} / \mathrm{v})$ and Knockout Serum Replacer (10\% v/v) compared with fetal bovine serum (10\% v/v)supplemented medium for the culture of FT19-1 and VIVOT-199. Numbered proteins are the following: 2, Heat-shock cognate 71 kDa protein (Mus musculus-from STO feeder-cells); 6, 2-oxo-4hydroxy-4-carboxy-5-ureidoimidazoline decarboxylase (Bos taurus); 7, Destrin (Bos taurus); 8, Cofilin-1 (Bos taurus); 9, Eukaryotic translation initiation factor $5 \mathrm{~A}-1$ (Bos taurus)

similar results (Figure S2). Serum-free conditioned media from JF3 and CT-1 cells were separated by denaturing-polyacrylamide gel electrophoresis followed by tandem mass-spectrometry analysis of the

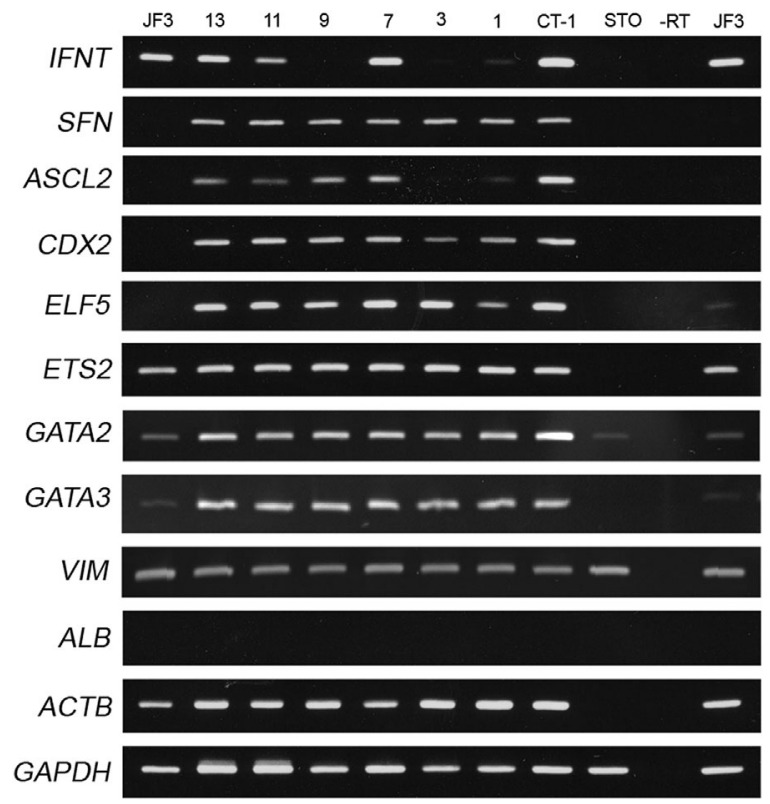

FIGURE 6 Semi-quantitative reverse-transcription PCR assay of trophectoderm marker genes. Passages for each iBT line used for this assay were as follows: iBT-1 (P11), iBT-3 (passage unknown), iBT-7 (P19), iBT-9 (P3), iBT-11 (P3), iBT-13 (P3), CT-1 (passage unknown), and JF3 (P2). STO, mouse STO feeder cells alone; JF3, Jersey fetus- 3 liver-derived fibroblasts used to create iBT cell lines by reprogramming-factor induction; - $\mathrm{RT}$, without reverse transcription. ACTB (Beta-actin) and GAPDH (Glyceraldehyde 3-phosphate dehydrogenase) were used as gene expression controls (GAPDH primers anneal to both bovine and mouse sequences); ALB (Albumin) was a cell-type-specific negative control. IFNT, Interferontau; SFN, Stratifin; ASCL2, Achaete-scute complex homolog 2; CDX2, Caudal type homeobox 2; ELF5, E74-like factor 5; ETS2, Erythroblastosis virus E26 oncogene homolog 2; GATA2, GATA binding protein 2; GATA3, GATA binding protein 3; VIM, Vimentin (primers specify both bovine and mouse sequence)

contents of gel bands between approximately 17 and $25 \mathrm{kDa}$ (the analyzed gel bands are numbered, as shown in Figure S3, and the gel bands' correspondence to the IFNT peptides detected are listed in the gel band column of the Supplementary Proteomics Data File). Interferon-tau precursor protein-3 peptides were detected in the JF3 conditioned medium from gel bands 23 and 24 (Figure S3 and Supplementary Proteomics Data File). Therefore, JF3 cells secreted IFNT3 under our culture conditions, and, based on the relatively low associated spectral counts, did so at a relatively low level (see Supplementary Proteomics Data File, exclusive spectral count column). Mass spectrometry analysis also confirmed that the CT-1 cells secrete IFNT protein-specifically, IFNT2, IFNT3, and IFNTc1.

\section{5 | Comparative expression of reprogramming factors genes in $\mathrm{BBT}$ cell lines}

Analysis of the integration and expression of the transduced (ectopic) human reprogramming factors in the $\mathrm{BBT}$ cell lines was performed by $P C R$ and semi-quantitative reverse-transcription $P C R$, respectively. The integrations of all the reprogramming factors may or may not have been successful in the nascent iBT cells, but, if they were all successful, not all were maintained in the cells after their establishment as cell 


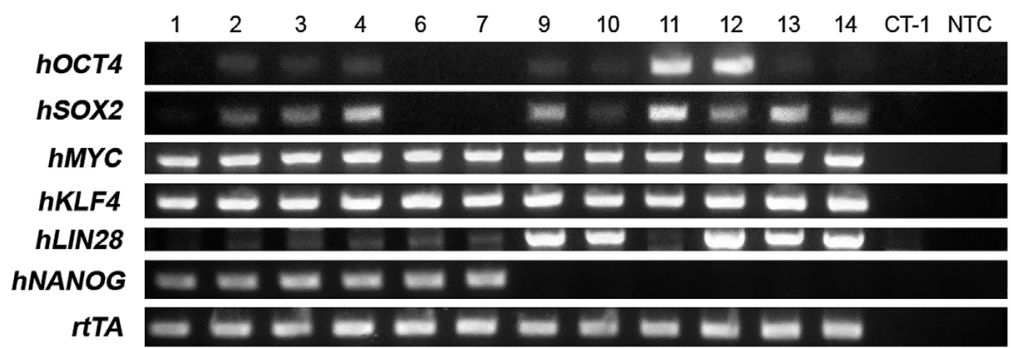

FIGURE 7 PCR detection of viral vector gene integration of human reprogramming factors in the iBT lines. The CT-1 bovine trophectoderm cell line (Talbot et al., 2000) was included as a negative control. NTC, no-template control (total RNA from the iBT-1 cell line that was not treated with reverse transcriptase)

lines. Integration of the hSOX2 gene construct was present in the majority of the iBT cells lines-except iBT-1, -6, and -7 (Figure 7)-and hPOU5F1 (hOCT4) integration was detected in most of the iBT cell lines-except iBT-1, -6, -7, and -14 (Figure 7). Amplicon levels of hSOX2 and hPOU5F1 varied from one iBT cell line to another. The attempted 8-factor transduction was not fully successful in that none of the iBT cell lines showed integration of the hTERT and SV4OTAg genes (Figure S1A). The hNANOG construct was integrated in lines iBT-1 to -7, from the 6-factor transduction experiment, whereas none of the iBT cell lines from the 8-factor transduction showed integration of hNANOG (lines iBT-9 to -14) (Figure 7). Integration of hLIN28, hMYC, and $h K L F 4$ genes appeared to be detectable in all of the iBT cell lines (Figure 7). The bovine trophectoderm cell line, CT-1, was negative for all of the human reprogramming-factor genes (Figure 7).

Expression of the exogenous human reprogramming factor genes was minimal in most of the iBT cell lines (Figure 8). Expression of the hMYC, hSOX2, or hLIN28 was not detected in any of the iBT cell lines. Expression of $h P O U 5 F 1$ was mostly absent across the iBT cell lines, except for iBT-4 and iBT-13. Robust expression of hKLF4 was found only in line iBT-6, although it was also detectable in lines iBT-7, -13, and -14 . Of the cell lines with integrated $h N A N O G$, only lines iBT-1 and iBT-3 exhibited detectable hNANOG transcription (Figure 7 versus 8). CT-1 cells were negative for transcripts of the human reprogramming factor genes, as expected (Figure 8).

Expression of endogenous bovine POU5F1, SOX2, KLF4, MYC, LIN28, and NANOG orthologs was also assessed by semi-quantitative reverse-transcription PCR using bovine-specific primers (Table 3;
Figure 9). Endogenous bPOU5F1 expression was not detected or showed relatively low abundance in the iBT cell lines, which is similar to the CT-1 cell line. Expression of bSOX2 was not detected in any of the iBT cell lines (Figure 9). Bovine KLF4 expression was found in most of the iBT cell lines, but, again, its expression was relatively low, with the exception of iBT-6; CT-1 cells also had relatively low bKLF4 expression. The iBT cell lines did not express bNANOG or bTERT (Figure 9; the positive signals in the CT-1 sample lane were generated from CT-1 genomic DNA, not CDNA, to verify PCR primer specificity and function). $b M Y C$ and $b$ LIN28 were expressed in all the iBT cell lines, as in CT-1 bovine trophectoderm cells (Figure 9).

\section{3 | DISCUSSION}

The most significant finding of the study was that stable trophectoderm cell lines were readily derived from the ectopic expression of reprogramming factors in bovine fibroblasts, particularly fibroblasts derived from fetal bovine liver tissue. These iBT cell lines had characteristics similar to those of the bovine blastocyst-derived trophectoderm cell line, CT-1, including cell morphology, IFNT secretion (Talbot et al., 2000), and the expression of several trophectoderm marker genes, such as CDX2 (Berg et al., 2011; Schiffmacher \& Keefer, 2013), ASCL2 (Guillemot, Nagy, Auerbach, Rossant, \& Joyner, 1994), ELF5 (Donnison et al., 2005), GATA2, and GATA3 (Bai et al., 2011; Home et al., 2009). The iBT cell lines also expressed endogenous reprogramming factor

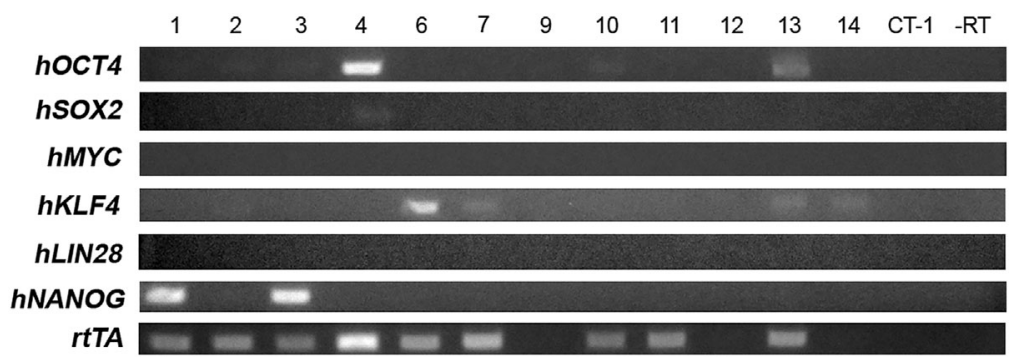

FIGURE 8 Semi-quantitative reverse-transcription PCR for human reprogramming gene expression in iBT lines. The CT-1 bovine trophectoderm cell line (Talbot et al., 2000) was included as a negative control. The passages at which the cells were assayed were: iBT-1 (P22), iBT-2 (P15), iBT-3 (P15), iBT-4 (P11), iBT-6 (P11), iBT-7 (P11), iBT-9 (P13), iBT-10 (P16), iBT-11 (P14), iBT-12 (P11), iBT-13 (P7), iBT-14 (P11), CT-1 (P38), and JF3 (P3). -RT, total RNA from the iBT-1 cell line that was not treated with reverse transcriptase 


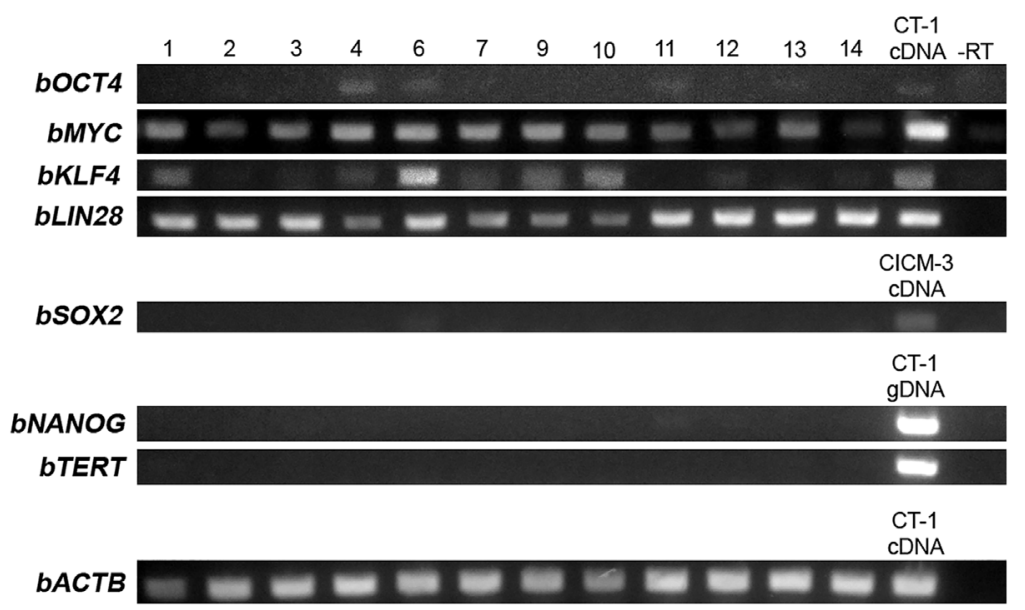

FIGURE 9 Semi-quantitative reverse-transcription PCR for endogenous bovine reprogramming factor ortholog gene expression in iBT lines. The CT-1 bovine trophectoderm cell line (Talbot et al., 2000), derived from a bovine blastocyst, was included as a comparative control or positive control, either as cDNA or as genomic DNA (gDNA), respectively. cDNA of the CICM-3 cell line, a bovine epiblast-derived neuronal cell line (Talbot, Powell, \& Garrett, 2002), was used as a positive control for bovine SOX2 expression. -RT, total RNA from the iBT-1 cell line that was not treated with reverse transcriptase

genes in a similar manner to CT-1 cells. This bovine-fetal-fibroblast reprogramming result contrasts with the porcine-fetal-fibroblast positive control reprogramming assays that were performed in parallel: using the same vectors, the pig cells were reprogrammed with relatively high efficiency (several dozen ESC-like colonies per 10-cm plate), and two dozen putative pig iPSC cell lines were easily established (data not shown). Therefore, in our hands and with our bovine fetal fibroblasts, the reprogramming efficiency of bovine cells was qualitatively and quantitatively different from that of porcine cells.

We did not assess exogenous or endogenous reprogramming factor expression, either on a per-cell or on a per-cohort basis, during and immediately after reprogramming-i.e., from the time the initial fibroblast-to-trophectoderm differentiation occurred or during the initial colony-cloning and primary expansion of the iBT cell lines. The cell lines were assayed for reprogramming factor expression only after multiple passages, and after several months in continuous culture. Thus, no discussion on the role of the "core" pluripotency factors (POU5F1, SOX2, NANOG), and the perhaps more ancillary factors (KLF4, LIN28, and MYC), in the induction of bovine trophectoderm from fibroblasts is possible; however, the presented gene expression data of the reprogramming factors from the established iBT cell lines can be compared to the previously reported expression of these factors in ungulate trophectoderm and also to their expression in mouse and human trophectoderm, ESC-derived trophectoderm, and induced mouse trophectoderm.

Trophectoderm specification and maintenance is characterized by the expression, or lack of expression, of the reprogramming factor genes (POU5F1, SOX2, KLF4, MYC, NANOG, and LIN28). In the mouse and human, a reduction or cessation of NANOG and POU5F1 expression is typical in the early blastocyst trophectoderm, blastocyst-derived trophectoderm cell lines, and when the trophectoderm differentiates from ESCs in culture (Benchetrit et al., 2015; Carey,
Choi, Wilson, Floer, \& Knott, 2014; Chen et al., 2009; Hyslop et al., 2005; Li et al., 2007; Niakan \& Eggan, 2013; Nichols et al., 1998; Niwa, Miyazaki, \& Smith, 2000; Strumpf et al., 2005). Similarly, "directly" induced mouse trophectoderm stem cells which do not proceed through an ESC or iPSC intermediate, also showed no expression of Nanog or Pou5f1 (Benchetrit et al., 2015; Kubaczka et al., 2015). Low expression of NANOG and POU5F1 was also reported for the in vivoderived trophectoderm of pre-implantation porcine blastocysts in comparison to their expression in epiblast and hypoblast tissue (du Puy, Lopes, Haagsman, \& Roelen, 2011; Fujii et al., 2013; Gao et al., 2011). Indeed, Ezashi et al. showed POU5F1 expression to be relatively low in porcine induced trophectoderm cells compared to porcine iPSCs (Ezashi et al., 2011). The expression of POU5F1 and NANOG in the iBT cell lines and in CT-1 bovine trophectoderm cells was low or absent, which is in contrast to their relatively high expression in the early trophectoderm and in the epiblast of the early bovine blastocyst (Berg et al., 2011; Degrelle et al., 2005; Fujii et al., 2010; Maruotti et al., 2012; Ozawa et al., 2012). So the phenotype of the iBT cell lines is equivalent to the late-stage, peri-implantation bovine blastocyst's trophectoderm in that POU5F1 and NANOG expression is largely silenced in the trophectoderm of the filamentous-stage bovine blastocyst (Berg et al., 2011; Degrelle et al., 2005; Maruotti et al., 2012).

Coincident with the reduced POU5F1 and NANOG expression is an increased CDX2-to-POU5F1 ratio. All the iBT cell lines assessed express CDX2. An increase in CDX2 expression, combined with a diminution of POU5F1 and NANOG expression, appears to be a universal prerequisite for trophectoderm formation and maintenance among mammals (Berg et al., 2011; Fujii et al., 2013; Niakan \& Eggan, 2013; Niwa et al., 2005; Ozawa et al., 2012; Sritanaudomchai et al., 2009; Strumpf et al., 2005), although data from some bovine embryo developmental gene expression profiling may not entirely support this scenario (Degrelle et al., 2005; Goissis \& Cibelli, 2014). For example, 
NANOG transcription was reportedly present in bovine trophectoderm/yolk sac-endoderm tissue from later-stage ovoid and elongated bovine blastocysts (Degrelle et al., 2005). At the protein level, however, NANOG was undetectable in the trophectoderm of laterstage bovine embryos (Maruotti et al., 2012). Ectopic hNANOG expression observed in our iBT-1 and iBT-3 lines did not appear to change the essential trophectoderm phenotype, although ASCL2 expression was absent in both lines, which correlates with the reported suppression of Ascl2 expression by Nanog in a mouse ESC loss-of-function system (Ivanova et al., 2006). As with POU5F1 gene expression, the relative abundance of NANOG compared to CDX2 in our iBT cell lines may be of most importance (Chen et al., 2009; Hyslop et al., 2005)-although species differences in NANOG expression among preimplantation embryo have been noted, and could complicate interpretations (Kuijk et al., 2008).

Exogenous $h S O X 2$ and endogenous bSOX2 expression was absent in all 13 iBT cell lines. Variation in SOX2 expression, both up and down, is associated with trophectoderm specification and development (Avilion et al., 2003; Keramari et al., 2010). For example, Sox2 transcripts were essential for mouse embryo progression from the morula stage to the blastocyst stage, with concomitant trophectoderm formation (Keramari et al., 2010). Also, Sox 2 expression is apparently maintained in some, but not all, mouse trophectoderm stem cell lines (Kuckenberg et al., 2011; Wu et al., 2011), and its expression was highly active in mouse induced trophectoderm stem cells (Benchetrit et al., 2015). Overexpression of SOX2 resulted in the differentiation of human and mouse ESCs into trophectoderm (Adachi, Suemori, Yasuda, Nakatsuji, \& Kawase, 2010; Kopp, Ormsbee, Desler, \& Rizzino, 2008), and reducing SOX2 expression in human ESCs (Adachi et al., 2010) or Sox2 inhibition or knockdown in murine ESCs also caused trophectoderm differentiation ( $\mathrm{Li}$ et al., 2007). Thus, a narrow range of SOX2 expression is needed to prevent differentiation (Kopp et al., 2008). Indeed, cessation of SOX2 expression is observed in the in vivoderived trophectdoderm of pre-implantation porcine blastocysts compared to the epiblast and hypoblast tissue (du Puy et al., 2011; Fujii et al., 2013; Gao et al., 2011), while porcine trophectoderm stem cell lines displayed no SOX2 expression (Suasnavas et al., 2015). Similarly, SOX2 expression is down-regulated in the trophectoderm of elongating bovine blastocysts (Degrelle et al., 2005). Therefore, the absence of SOX2 expression, ectopic or endogeneous, in the iBT cell lines is consistent with known ungulate trophectoderm gene expression.

KLF4 expression does not appear to be required for trophectoderm induction (Segre, Bauer, \& Fuchs, 1999), whereas KLF5 is vital for its formation (Lin, Wani, Whitsett, \& Wells, 2010). Expression of Klf4 was down-regulated in mouse trophectoderm stem cells (Kuckenberg et al., 2011; Wu et al., 2011), which is in contrast to the expression of bovine KLF4 in many of the iBT cell lines and the additional expression hKLF4 in the iBT-6 line. Other findings, however, are consistent with KLF4 expression in the iBT cell lines, including its expression in human syncytiotrophoblast cells ( $\mathrm{Li}$ et al., 2013), its up-regulation in differentiating BeWo choriocarcinoma cells (White, Declercq, Arfuso, Charles, \& Dharmarajan, 2009), and its expression in the trophectoderm of in vitro-produced bovine blastocysts (Madeja et al., 2013).
Bovine MYC was uniformly expressed in all the iBT cells lines, whereas the exogenous $h M Y C$, which was integrated into all of the iBT cell lines, was not. The expression of endogenous bovine MYC in the cell lines is consistent with the demonstrated maintenance of Myc expression in mouse trophectoderm stem cells (Erlebacher, Price, \& Glimcher, 2004); MYC overexpression inducing trophectoderm differentiation from human ESCs (Sumi, Tsuneyoshi, Nakatsuji, \& Suemori, 2007); high expression of MYC in proliferative human cytotrophoblast tissue (Rydnert, Pfeifer-Ohlsson, Goustin, \& Ohlsson, 1987); MYC up-regulation in the cytokine-induced proliferation of human cytotrophoblast cells (Pu et al., 2012); MYC up-regulation in the trophectoderm of bovine blastocysts treated with epidermal growth factor (Tetens, Kliem, Tscheudschilsuren, Navarrete Santos, \& Fischer, 2000); and ectopic MYC expression increasing the efficiency of mouse induced trophectoderm stem cell derivation from embryonic fibroblasts (Benchetrit et al., 2015).

In contrast to the other reprogramming factors, LIN28 has only recently been reported to contribute to trophectoderm cell biology. Lin28 protein is present in the trophectoderm of the early postimplantation mouse (Yang \& Moss, 2003), in the pre-implantation mouse blastocyst's inner cell mass and trophectoderm, and in the marmoset blastocyst's trophectoderm (Vogt, Meglicki, Hartung, Borsuk, \& Behr, 2012). In vitro analysis of mouse trophectoderm stem cells and a human trophoblast cell line linked reductions in LIN28 expression to the terminal differentiation of trophectoderm cells, that is, functional maturation or cell syncytialization (Seabrook et al., 2013). Therefore, the relatively robust and consistent expression of endogenous bovine LIN28 among the iBT cell lines suggests that the trophectoderm phenotype of these cell lines is analogous to the trophectoderm of the pre-implantation bovine embryo, particularly during the rapid expansion phase of bovine blastocyst development (Betteridge, Eaglesome, Randall, \& Mitchell, 1980).

The second significant result of this study was our inability to repeat the findings of others who reported that ectopic expression of OSKM or OSKMNL in bovine fetal fibroblasts enables their reprogramming into an ESC-like state with ESC morphology and ESC marker expression-e.g., AP expression and activity, which is the most consistent and earliest indicator of successful iPSC reprogramming (Brambrink et al., 2008; Cao et al., 2012; Cravero et al., 2015; Han et al., 2011; Heo et al., 2015; Kawaguchi et al., 2015; Nong et al., 2015; Sumer et al., 2011; Talluri et al., 2015). Although colonies of cells with ESC-like morphology were observed in some of our experiments, the iPSC-like cell lines resulting from these colonies were uniformly AP-negative. One group reported relatively low bovine iPSC isolation efficiency with the use of six reprogramming factors (Talluri et al., 2015), whereas others indicated that isolation and establishment of bovine iPSC, based on morphological appearance, was achieved without great difficulty using either four or six reprogramming factors (Cravero et al., 2015; Han et al., 2011; Nong et al., 2015; Sumer et al., 2011). None of the other bovine iPSC reports mention observing trophectoderm-like colonies in their primary induction culture plates, so we cannot be certain that they occurred.

In our experiments, colonies of induced epithelial cells in primary culture usually acquired trophectoderm cell morphology and colony 
characteristics-e.g., the dome-formation clearly visible in AP-positive colonies [high AP expression was shown in the trophectoderm of early bovine blastocysts (Talbot et al., 1995)]. Thus, our major results contrast those of other published bovine iPSC-derivation reports, even given the possibility that rare AP-positive iPSC colonies were present, but somehow missed, in our primary transduction plates. By comparison, during the derivation of OSKM-induced pig trophectoderm cell lines, nascent trophectoderm colonies comprised a relatively minor proportion ( $17 \%$ of those picked) of the reprogrammed colonies (Ezashi et al., 2011). Similar to our observations with bovine fetal fibroblast reprogramming, the occurrence of colonies that were trophectoderm in nature depended on the cell type being reprogrammed-that is, when pig umbilical cord-derived fibroblasts rather than whole-body pig fetal fibroblasts were transduced with OSKM, $79 \%$ of the resulting reprogrammed colonies were judged to be trophectoderm-like (Ezashi et al., 2011).

Reprogramming results may vary according to the culture methods and medium employed. Variations in growth factor supplementation, usually involving leukemia inhibitory factor (LIF) and basic fibroblast growth factor (bFGF), and the choice of feeder cells employed are common among the existing bovine iPSC reports. Exposure to compounds, such as inhibitors of glycogen synthase kinase three beta (GSK3B) and MAPK/ERK kinase (MEK) (i.e., $2 i$ medium conditions), were also claimed to enhance bovine cell reprogramming (Heo et al., 2015; Kawaguchi et al., 2015). The various culture methods, growth factors, and small molecules we employed were expected to improve the chances of generating bovine iPSC cells (Gafni et al., 2013; Huangfu et al., 2008; Silva et al., 2008; Telugu et al., 2010) and to inhibit the formation and growth of trophectoderm cells (Kwiecińska, Wiśniewska, \& Gregoraszczuk, 2011; Lu et al., 2008). Indeed, our experimental methods were similar to those used by other laboratories that reported the successful creation of iPSCs in general and ungulate iPSCs specifically. Therefore, other biological factors or processes may have played a more significant role in the reprogramming result obtained herein.

The apparently "direct" somatic cell reprogramming-i.e., induced differentiation of bovine fibroblasts directly to trophectoderm-we observed may have been caused by the degree of transduced human reprogramming factor expression, the successful expression of only a subset of the transduced human factors, or variation in the degree of expression of particular factors. The direct generation of various somatic cell types by ectopic expression of OSKM has been reported for the reprogramming of mouse and human cells. This OSKMmediated conversion from one somatic cell type to another was correlated with the temporal expression of reprogramming factors during the first days or week of the attempted cell reprogramming. Mikkelsen et al., for example, showed that stable cell lines with intermediate states of cellular reprogramming could be isolated, and that each had distinct gene expression and chromatin states compared to fully reprogrammed iPSCs (Mikkelsen et al., 2008). Kim et al. subsequently reported that relatively brief durations of OSKM expression (3-6 days) in mouse fibroblasts enabled the induction and isolation of replicating neural progenitor cells without an intermediate iPSC stage; however, long-term OSKM expression was necessary for an internal Nanog-GFP reporter to be activated and iPSC characteristics to be acquired (Kim et al., 2011). Somatic cell fate resulting from short-term expression of OSKM appeared to be dependent on extrinsic factors since, in related work from the same laboratory, exposure of cells to alternate medium constituents gave rise to cardiac muscle cells instead of neuronal progenitor cells (Efe et al., 2011). Another group also demonstrated direct induction of neural progenitor cell lines by limiting Pou5f1 expression in the initial phase of the mouse fibroblast OSKM reprogramming (Thier et al., 2012). Similarly, short-term OSKM exposure (4 days) resulted in partially reprogrammed human fibroblasts, termed PiPCs, that were negative for pluripotency marker expression and teratoma formation but could be differentiated into other somatic cells, such as endothelial cells, under defined culture conditions (Margariti et al., 2012). Thus, a short period of reprogramming factor expression or a failure of some of the factors to integrate and express may have caused incomplete reprogramming and the generation of the trophectoderm observed in our experiments.

Two characteristics of the iBT cell lines, IFNT and ELF5 expression, varied from those of previously reported observations. Unlike bovine blastocyst-derived trophectoderm cell lines that maintain their production of IFNT over long-term passage (Talbot, Caperna, Powell, Garrett, \& Ealy, 2004; Talbot et al., 2000), greater than 50\% of the iBT lines stopped producing IFNT after a few passages under our standard culture conditions (co-culture on STO feeder cells in 10\% DMEM/high glucose). This may have occurred as a result of "epigenetic memory," wherein the fibroblast chromatin marks and associated factors were not completely removed in the reprogramming of the cells (Polo et al., 2010). Other possibilities include that the $i B T$ lines without IFNT expression may behave like the trophectoderm cells of the early blastocyst, in which IFNT expression is very low, or they may represent a maturing trophectoderm population, as IFNT expression is downregulated at about the time of bovine embryo implantation (Farin et al., 1990; Sakurai et al., 2012). The expression of ELF5, while present in the iBT lines and the CT-1 cell line, was not observed by Degrelle et al. or Pearton et al. in trophectoderm tissue of bovine blastocysts (Degrelle et al., 2005; Pearton, Broadhurst, Donnison, \& Pfeffer, 2011); however, Ozawa et al. reported ELF5 transcripts in their deep sequencing and quantitative PCR of 8-day bovine blastocyst trophectoderm tissue (Ozawa et al., 2012). Like the down-regulation of IFNT in the bovine embryo trophectoderm during the periimplantation period, ELF5 expression is hypothesized to be indicative of late trophectoderm development, maturation, or function in the bovine (Pfeffer \& Pearton, 2012), as proposed for the mouse (Ng et al., 2008).

We have shown, in contrast to the results of others, that the expression of OSKM and other reprogramming factors in bovine fibroblasts can result in the induction and isolation of bovine trophectoderm cell lines with similar characteristics to bovine trophectoderm lines derived from bovine blastocysts. These iBT cell lines may prove useful in experiments aimed at better understanding the complex interplay of reprogramming factors in somatic cell reprogramming, particularly in ungulates. The iBT cell lines, or the process of their derivation, may also prove useful as in vitro models 
from which to learn more about the molecular interactions between reprogramming factors and trophectoderm-differentiation-related transcription factors, including CDX2, ELF5, and EOMES (Pfeffer \& Pearton, 2012; Niwa et al., 2005; Schulz et al., 2008), and trophectoderm differentiation-related signal transduction factors, such as bone morphogenetic protein-4 (BMP4), nodal (NODAL), activin A (INHBA), and Fibroblast growth factors (Bernardo et al., 2011; Lee et al., 2011; Schulz et al., 2008; Tanaka, Kunath, Hadjantonakis, Nagy, \& Rossant, 1998; Xu et al., 2002).

\section{4 | MATERIALS AND METHODS}

Care and treatment of all animals used in this study were approved by the Institutional Animal Care and Use Committee of the Beltsville Agricultural Research Center, United States Department of Agriculture.

\section{1 | Cell culture}

Bovine fetal fibroblasts were established from two Jersey cow pregnancies, as previously described (Powell et al., 2004). The JF2 cells were derived from a male 64-day gestation fetus while JF3 cells were derived from a female 75-day gestation fetus. Fibroblasts derived from thigh tissue and liver, and endothelium-like cells derived from the Wharton's jelly of the umbilicus and from amniotic fluid, were separately cultured to establish finite cell lines from both fetuses. All the fetal bovine cell lines were established and grown in a $5 \% \mathrm{O}_{2} / 5 \%$ $\mathrm{CO}_{2} / 90 \% \mathrm{~N}_{2}$ atmosphere (low oxygen) with $10 \%$ DMEM (low-glucose DMEM [Hyclone, Logan, UT] supplemented with $10 \% \mathrm{v} / \mathrm{v}$ fetal bovine serum [FBS] [Atlanta Biologicals, Lawrenceville, GA] and $4 \mathrm{mM}$ L-glutamine), with the addition of $4 \mathrm{ng} / \mathrm{ml}$ basic fibroblast growth factor (bFGF) (R\&D Systems, Minneapolis, MN) and Primocin antibiotic (InvivoGen, San Diego, CA).

The preparation of feeder-cells was as previously described (Talbot, Sparks, Powell, Kahl, \& Caperna, 2012), using eight kRad of gamma radiation to inactivate CF-1 primary mouse embryonic fibroblasts (MEFs) or STO mouse fibroblasts (CRL 1503; American Type Culture Collection, Rockville, MD). Mouse fibroblasts were grown in $10 \%$ DMEM high glucose (Hyclone) supplemented with $4 \mathrm{mM}$ L-glutamine.

All cell lines were established and grown in tissue culture flasks (Greiner, Frickenhausen, Germany or Falcon, Becton/Dickson, Lincoln Park, NJ). For cryopreservation, all cell lines and primary cultures were frozen in $92 \% \mathrm{FBS} / 8 \%$ dimethyl sulphoxide (DMSO), and stored in liquid nitrogen vapor within 2-ml cryovials (Nunc, Denmark).

Knock-Out DMEM (KO-DMEM) was obtained from Invitrogen (Gaithersburg, MD). Other cell culture reagents, including Dulbecco's phosphate-buffered saline without $\mathrm{Ca}^{++}$and $\mathrm{Mg}^{++}$, trypsin-EDTA (0.05\% trypsin, $0.43 \mathrm{mM}$ ethylenediaminetetra acetic acid), and L-glutamine were purchased from Hyclone or Life Technologies (Grand Island, NY), unless specifically noted.

Alkaline phosphatase staining of cells was performed as previously described (Talbot et al., 1995).

\section{2 | Reprogramming factor viral vectors}

Lentiviral or retroviral vectors were prepared for the expression of human POU5F1 (OCT4), SOX2, KLF4, MYC, NANOG, LIN28, TERT, and the transforming viral gene, SV40TAg. Lentiviral constructs were doxycycline-inducible via the reverse tetracycline-controlled transactivator (rtTA) system (Gossen et al., 1995). The rtTA-containing viral vector was co-transduced into the bovine fetal fibroblasts along with the reprogramming factor-encoding viruses. Transcription of the reprogramming factors by rtTA was induced with doxycycline $(1 \mu \mathrm{g} / \mathrm{ml}$ ) (Sigma-Aldrich, St. Louis, MO).

The plasmids for SV40TAg, hTERT, and rtTA were procured from Addgene (pBABE-neo-largeTcDNA [\#1780], pBABE-neo-hTERT [\#1774], and FUW-M2rtTA [\#20342], respectively). The pBABEneo-large T cDNA and pBABE-neo-hTERT vectors utilized retroviral vectors that were not doxycycline inducible. The tet transactivator FUW-M2rtTA vector construct allowed for doxycycline induction.

The POU5F1, SOX2, KLF4, and MYC lentiviral vectors were kindly provided by Dr. R. Michael Roberts (University of Missouri); their creation was previously described (Ezashi et al., 2009). Briefly, each of the reprogramming factor genes from the pEP4-EO2S-EM2K or pEP4EO2S-EN2L parent plasmids (Telugu et al., 2010) were cloned into the FUW-tetO-lox-hKLF4 plasmid (Addgene \#20727), creating two bicistronic FUW-tetO-lox-O2S (expressing POU5F1/SOX2) and FUWtetO-lox-M2K (expressing MYC/KLF4) vectors. Creation of the NANOG and LIN28 vectors began with PCR amplification of the NANOG gene out of the pSin-EF2-NANOG-Pur plasmid (Addgene \#16578), and cloning it into the lentiviral vector FUW-tetO-lox-hOCT4 plasmid (Addgene \#20728), creating a new FUW-tetO-lox-NANOG vector (expressing NANOG). A 5' BamHI and a 3' BstBI site were also added to the vector using primer-linked insertion. The LIN28 gene was PCR amplified from the pSin-EF2-LIN28-Pur plasmid (Addgene \#16580), and cloned into the FUW-tetO-lox-NANOG vector at the BamHI and BstBI sites, creating a new FUW-tetO-lox-LIN28 vector (expressing LIN28). The FUWtetO-lox-O2S, FUW-tetO-lox-M2K, FUW-tetO-lox-NANOG, and FUWtetO-lox-LIN28 vectors were amplified in Top10 Escherichia coli, selected with ampicillin, and purified using a Maxiprep kit (Thermo Fisher Scientific; Waltham, MA). The identity of the vectors was confirmed through restriction endonuclease digestion analysis and sequencing. The lentiviral packaging vectors of psPAX2 and pMD2.G (Addgene\#12260 and 12259, respectively) were used to create replication-incompetent viral particles.

Transfection of the lentiviral and packaging vectors into the viralpackaging cell lines 293FT and Plat-A was performed as follows: Stock 293FT cells were cultured in 10\% DMEM containing $500 \mu \mathrm{g} / \mathrm{ml} \mathrm{G418}$ (Geneticin) (Life Technologies) for $48 \mathrm{hr}$, and then seeded at $4 \times 10^{6}$ cells per $10-\mathrm{cm}$ gelatin-coated dish. The following day, the cells were refed $2 \mathrm{hr}$ prior to transfection with $5 \mathrm{ml}$ of 10\% DMEM without G418. Cells were transfected with $3.5 \mu \mathrm{g}$ of pMD2.G, $5.85 \mu \mathrm{g}$ of psPAX2, and $3 \mu \mathrm{g}$ of FUW-M2rtTA and reprogramming plasmids (OSKMN and L). Each plasmid DNA was mixed with $250 \mu$ l of DMEM, and then gently mixed with $12.5 \mu \mathrm{l}$ of Polyjet (Signagen, Rockville, MD) diluted in $250 \mu$ l DMEM.

Transfection of the retroviral and packaging vectors into viral packaging cell line Plat-A was performed as follows: Stock Plat-A cells 
were grown and maintained in $10 \%$ DMEM containing $100 \mu \mathrm{g} / \mathrm{ml}$ Primocin (InvivoGen, San Diego, CA), $10 \mu \mathrm{g} / \mathrm{ml}$ blasticidin (SigmaAldrich), and $1 \mu \mathrm{g} / \mathrm{ml}$ puromycin (Sigma-Aldrich). Cells for virus production were seeded at $4 \times 10^{6}$ cells per $10-\mathrm{cm}$ gelatin-coated dish, in $10 \%$ DMEM without antibiotics. The following day, the dishes were refed with $5 \mathrm{ml}$ of $10 \%$ DMEM $2 \mathrm{hr}$ prior to transfection. Cells were transfected with $9 \mu \mathrm{g}$ of the SV4OTAg or hTERT plasmids suspended in serum-free DMEM $(250 \mu \mathrm{l})$ that was mixed with $27 \mu$ of Fugene (Genetech, San Francisco, CA).

The transfection mixtures were incubated for $15 \mathrm{~min}$ at room temperature, and $1.2 \mu \mathrm{l}$ of $6 \mu \mathrm{g} / \mathrm{ml}$ polybrene (Sigma-Aldrich) was added, except to those containing the SV4OTAg or hTERT constructs. The mixtures were then added drop-wise into the medium of the appropriate cells. Dishes were refed daily with $9 \mathrm{ml}$ of $2 \%$ DMEM, and the virus-containing medium was collected 2,3 , and 4 days posttransfection. The virus-containing media were spun for $7 \mathrm{~min}$ at $1,300 \mathrm{~g}$ to pellet cellular debris, and the supernatants were collected.

\subsection{Viral vector transduction, primary induced colony formation, and induced cell line isolation}

Viral supernatants were inoculated onto bovine cells, and mouse or pig cells as positive controls, seeded at $1 \times 10^{5}$ cells per well of a 6-well plate 1 day prior to transduction. The cells were transduced on Days 2 , 3 , and 4 with a combination of six or eight reprogramming factors. Cells receiving six reprogramming factors were transduced with $0.25 \mathrm{ml}$ of each viral supernatant of O2S, M2K, rtTA, NANOG, and LIN28 pseudotyped virus and $0.75 \mathrm{ml}$ of $10 \%$ DMEM with $1.2 \mu \mathrm{l}$ of $6 \mu \mathrm{g} / \mathrm{ml}$ polybrene for a total volume of $2.0 \mathrm{ml}$. Cells receiving eight reprogramming factors were transduced with $0.25 \mathrm{ml}$ of each viral supernatant as above plus those for SV40TAg and hTERT, and $0.25 \mathrm{ml}$ of $10 \%$ DMEM with $1.2 \mu \mathrm{l}$ of $6 \mu \mathrm{g} / \mathrm{ml}$ polybrene. The medium was changed on Day 4 post-transduction, and the cells were passaged onto CF-1 mouse feeder-layer cells or gelatin-coated $100-\mathrm{mm}$ plates at a 1:16 split ratio.

For reprogramming experiments from which the iBT cell lines were established, medium conditioned for $24 \mathrm{hr}$ by CF-1 feeder-cells was used. The iPSC medium employed was similar to those previously published (Telugu et al., 2011; Ying et al., 2008), and consisted of KO-DMEM supplemented with 20\% ES-FBS (Life Technologies), and, after conditioning by mouse CF-1 embryonic fibroblasts, the following were added to conditioned media for the given final concentration: $1 \mu \mathrm{g} / \mathrm{ml}$ doxycycline, $0.5 \mu \mathrm{M}$ PD0325901 (Stemgent, San Diego, CA), $3 \mu \mathrm{M}$ CHIR99021 (Stemgent), and $4 \mathrm{ng} / \mathrm{ml} \mathrm{bFGF}$. Other conditioned medium constituents included $1 \mathrm{mM}$ GlutaMAX (Life Technologies), $0.1 \mathrm{mM}$ 2-mercaptoethanol (Sigma-Aldrich), and $100 \mu \mathrm{M}$ nonessential amino acid (Life Technologies). One micromolar ( $1 \mu \mathrm{M})$ valproic acid (Stemgent) was included in the conditioned medium for the first 8 days post-transduction to improve iPSC induction (Huangfu et al., 2008).

The transduced bovine fetal fibroblasts were cultured under lowoxygen conditions $(5 \% \mathrm{v} / \mathrm{v})$. For initial expansion of the iBT cell lines, the cells were cultured in an ambient atmosphere and $5 \% \mathrm{CO}_{2}$ on STO feeder-cells with DMEM, high glucose, supplemented with $7.5 \%$ FBS,
10\% Knock-out Serum Replacer (KSR) (Life Technologies), and $8 \mathrm{ng} / \mathrm{ml}$ bFGF. For long-term culture-i.e., passage 3-5 and onward-the iBT cell lines were cultured in ambient atmosphere and $5 \% \mathrm{CO}_{2}$ on STO feeder-cells with $10 \%$ DMEM, high glucose, with $1 \mathrm{mM} \mathrm{N}$-acetyl cysteine supplementation.

\subsection{Immunoblot analysis of interferon-tau (IFNT) protein expression}

Induced bovine trophectoderm cell lines were grown in T12.5 flasks on STO feeder-layers in 10\% DMEM. For preparation of serum-free conditioned medium, the iBT cultures were washed four times with serum-free DMEM, and refed with $2 \mathrm{ml}$ of serumfree DMEM. The medium was collected after $48 \mathrm{hr}$, centrifuged to remove cell debris, and kept frozen at $-75^{\circ} \mathrm{C}$ until analyzed. One-dimensional sodium dodecyl sulfate polyacrylamide gel electrophoresis (SDS-PAGE) was performed on neat serumfree conditioned medium samples mixed with freshly prepared $4 \mathrm{X}$ loading buffer (3:1), and the equivalent of $30 \mu$ l of medium was loaded per lane. Separated proteins were transferred onto polyvinylidine difluoride membranes (Immobilon-P) (Millipore Corp, Bedford, MA) using a semi-dry blotting system (BIORAD, Hercules, CA). All blots were stained with Coomassie Brilliant Blue to visualize total proteins, and the presence of IFNT in the serum-free conditioned medium was evaluated by exposing the blots to anti-bovine IFNT antiserum (generously provided by Dr. R. Michael Roberts, University of Missouri). Antibody binding was detected using the appropriate horseradish peroxidaselabeled secondary antibody, developed with Pierce ECL plus reagent (\#32132; Thermo Fisher Scientific), and visualized by densitometry on a Typhoon (GE Healthcare, Piscataway, NJ).

\section{5 | Interferon-tau antiviral assay}

Forty-eight-hour conditioned medium (10\% DMEM) was collected from $\mathrm{T} 12.5$ cultures of $\mathrm{iBT}$ lines at $\geq 50 \%$ confluency. The conditionedmedium samples were stored frozen at $-75^{\circ} \mathrm{C}$ prior to the antiviral assay, which was performed as previously described (Roberts et al., 1989) with the following modifications. Assays were completed in duplicate, and results were reported in international units (IU) of IFNT per $\mathrm{ml}$ of culture medium. Assay of conditioned medium from the CT-1 cell line was performed as a positive control and for comparison to a blastocyst-derived trophectoderm cell line. Negative controls included conditioned medium from STO feeder cells alone and unconditioned medium.

\subsection{Two-dimensional gel electrophoresis and tandem mass spectrometry}

The cellular proteins of the iBT lines were separated by twodimensional gel electrophoresis and identified by mass spectrometry, as previously described (Talbot et al., 2010). Cellular proteins were extracted from a single T25 tissue culture flask of each cell line, at $75-100 \%$ confluency. 
TABLE 2 Primers for human reprogramming factor and rtTA (integration and expression)

\begin{tabular}{|c|c|c|}
\hline Gene & Primers & Addgene identifier \\
\hline \multirow[t]{2}{*}{ Human Pou class 5 homeobox 1 (hPOU5F1, a.k.a., hOCT4) } & 5'-CACTTCACTGCACTGTACTCCTC & \multirow[t]{2}{*}{20925} \\
\hline & 5'-CTAGGAATGCTCGTCAAGAAGAC & \\
\hline \multirow[t]{2}{*}{ Human SRY (sex-determining region)-box 2 (hSOX2) } & 5'-TTTCCTTTGAAAAACACGATGAT & \multirow[t]{2}{*}{20923} \\
\hline & 5'-GTCTCCGACAAAAGTTTCCACT & \\
\hline \multirow[t]{2}{*}{ Human Kruppel-like factor 4 (hKLF4) } & 5'-СTTTATTCTCTCCAATTCGCTGA & \multirow[t]{2}{*}{20923} \\
\hline & 5'-ATGTACACCGGGTCCAATTCT & \\
\hline \multirow[t]{2}{*}{ Human vMyc avian myelocytomastosis viral oncogene homolog (hMYC) } & 5'-ACAACCGAAAATGCACCAGC & \multirow[t]{2}{*}{20923} \\
\hline & 5'-GGCCCTCACATTGCCAAAAG & \\
\hline \multirow[t]{2}{*}{ Human Lin28 homolog A (hLIN28) } & 5'-ATCAGCCATATGGTAGCCTCAT & \multirow[t]{2}{*}{$\mathrm{n} / \mathrm{a}^{\mathrm{a}}$} \\
\hline & 5'-AGAATCCAGGTGGCAACACAG & \\
\hline \multirow[t]{2}{*}{ Human Nanog homeobox (hNANOG) } & 5'-GCCTGAAGAAAACTATCCATCCT & \multirow[t]{2}{*}{16578} \\
\hline & 5'-TTCTGGTCTTCTGTTTCTTGACC & \\
\hline \multirow[t]{2}{*}{ Human telomerase reverse transcriptase ( $h T E R T)$} & 5'-CTGGAACCATAGCGTCAGG & \multirow[t]{2}{*}{1774} \\
\hline & 5'-CACAGAAACCACGGTCACTC & \\
\hline \multirow[t]{2}{*}{ Simian virus 40 large $T$ antigen (SV4OTAg) } & 5'-AGCCACAGGTCTGTACCAAATTA & \multirow[t]{2}{*}{1780} \\
\hline & 5'-AATATTTCCCCCTGGAATAGTCA & \\
\hline \multirow[t]{2}{*}{ Reverse tetracycline transactivator $(r t T A)$} & 5'-AACAGTACGAAACCCTGGAAAAT & \multirow[t]{2}{*}{20342} \\
\hline & 5'-GCTCAATTGCTTGTCTCAGAAGT & \\
\hline
\end{tabular}

${ }^{\mathrm{a}}$ This vector was specially created for this experiment, and has no reference number.

\section{7 | Confirmation of viral vector integration by PCR}

Genomic DNA (gDNA) was prepared from T12.5 flasks of each iBT line using the DNeasy kit (Qiagen, Valencia, CA), according to the manufacturer's recommendations. The gDNA was quantified by spectrophotometry using a Nanodrop (Thermo Scientific). One-half microgram of gDNA was used as the template in PCR reactions, and JumpStart ${ }^{\mathrm{TM}}$ REDTaq ${ }^{\circledR}$ ReadyMix $^{\mathrm{TM}}$ reaction mix (Sigma-Aldrich) was used, following the manufacturer's suggestions, with a final reaction volume of $50 \mu \mathrm{l}$. A T100 thermal cycler (Bio-Rad, Hercules, CA) was used for amplification under the following cycling parameters: $95^{\circ} \mathrm{C}$ for $3 \mathrm{~min}$ (initial denaturation); then $35 \mathrm{cycles}$ each of $95^{\circ} \mathrm{C}$ for $30 \mathrm{sec}$ (denaturation), $55^{\circ} \mathrm{C}$ for $30 \mathrm{sec}$ (annealing), and $72^{\circ} \mathrm{C}$ for $1 \mathrm{~min}$ (extension); plus a final $72^{\circ} \mathrm{C}$ for $5 \mathrm{~min}$ (final extension).

\section{8 | Semi-quantitative reverse-transcription PCR}

Total RNA from the cells was prepared using the RNeasy Mini Kit (Qiagen), according to the manufacturer's instructions. RLT lysis buffer was added directly to iBT cultures in T12.5 flasks that were $50-90 \%$ confluent. A double digestion with DNase I, once on column and another post-extraction in solution, was performed to remove contaminating genomic DNA as part of the isolation procedure. One microgram of total RNA was reverse-transcribed using the iScript reverse-transcription kit (Bio-Rad; Hercules, CA), according to manufacturer's directions: $25^{\circ} \mathrm{C}, 5 \mathrm{~min} ; 42^{\circ} \mathrm{C}, 30 \mathrm{~min} ; 85^{\circ} \mathrm{C}, 5 \mathrm{~min}$. The resulting CDNA was diluted to a concentration of $12.5 \mathrm{ng} / \mu \mathrm{l}$.

PCR amplification was carried out with $2 \mu$ of diluted cDNA using either DreamTaq DNA polymerase (Thermo Fisher Scientific) or JumpStart ${ }^{\mathrm{TM}}$ REDTaq $^{\circledR}$ ReadyMix ${ }^{\mathrm{TM}}$ reaction mix (Sigma-Aldrich),

TABLE 3 Primers for endogenous bovine reprogramming factor orthologs (reverse-transcription PCR)

\begin{tabular}{|c|c|c|}
\hline Gene & Primers & Genbank identifier \\
\hline Bovine Pou class 5 homobox1 (POU5F1, a.k.a., OCT4) & 5'-CGCCCTATGACTTGTGTGGA & NM_174580.2 \\
\hline Bovine SRY (sex-determining region)-box 2 (SOX2) & 5'-CACATGTCCCAGCACTACCA & NM_001105463.2 \\
\hline Bovine Kruppel-like factor 4 (KLF4) & $\begin{array}{l}\text { 5'-AGCGTACCGGGTTTTTCTCC } \\
\text { 5'-CCTTACACATGAAGAGGCACTTT } \\
\text { 5'-TGTCTTTTGGTTTCCTTGTGTCT }\end{array}$ & NM_001105385 \\
\hline Bovine vMyc avian myelocytomatosis viral oncogene homolog (MYC) & $\begin{array}{l}\text { 5'-CCCCCAAGGTAGTTATCCTTAAA } \\
\text { 5'-AATGAGAATTTCCTGAGGGAGTC }\end{array}$ & NM_001046074 \\
\hline Bovine Lin28 homolog A (LIN28) & $\begin{array}{l}\text { 5'-AGACAGGTGCTACAACTGTGGAG } \\
\text { 5'-GGCAGAGCTATGGATCTCTTCTT }\end{array}$ & NM_001193057 \\
\hline Bovine Nanog homeobox (NANOG) ${ }^{a}$ & $\begin{array}{l}\text { 5'-ACACCCGGAGATCTTCACCT } \\
\text { 5'-GAGACAGTGTCCGTGTCGAG }\end{array}$ & NM_001025344 \\
\hline Bovine telomerase reverse transcriptase $(T E R T)^{a}$ & $\begin{array}{l}\text { 5'-CGGACACTCGTGGAAACCAT } \\
\text { 5'-ACACCAGGGCACTTCTGATG }\end{array}$ & NM_001046242 \\
\hline Bovine beta actin (ACTB) & $\begin{array}{l}\text { 5'-CATTGTTACAGGAAGTCCTTTGC } \\
\text { 5'-GATGGCTGTCCATTCAAAATAAA }\end{array}$ & NM_173979 \\
\hline
\end{tabular}

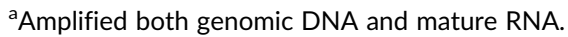


TABLE 4 Primers for trophectoderm cell markers (reverse-transcription PCR)

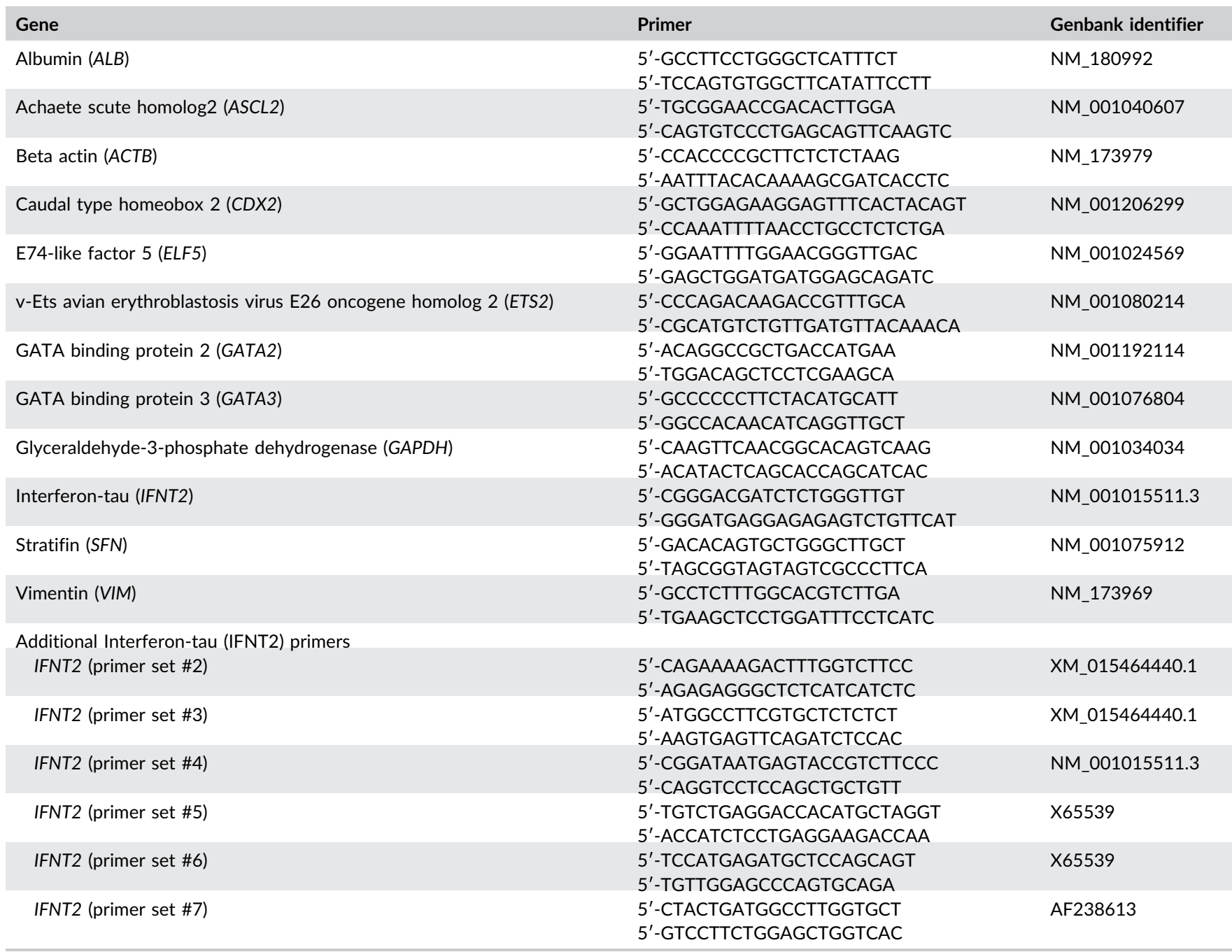

following the manufacturer's suggestions for each, in a final reaction volume of $50 \mu \mathrm{l}$. The amplification conditions for human and bovine transcript analysis were the same as described above for genomic PCR. The reverse-transcription PCR products from the DreamTaq protocol were mixed with $10 \mu \mathrm{l}$ of 6X Purple Gel Loading Dye (New England BioLabs, Ipswich, MA) before separation on a $1.5 \%$ agarose Trisacetate-EDTA gel with $10 \mu \mathrm{g} / \mathrm{ml}$ ethidium bromide (Sigma-Aldrich), and then visualized on an ultraviolet transilluminator (Vilber Lourmat, Marne La Vallée, France). Gene-specific primers for bovine trophectoderm markers and reprogramming factors (below) were synthesized according to bovine- and human-specific sequences obtained from GenBank (http://www.ncbi.nlm.nih.gov/entrez/query.fcgi) or The Computational Biology and Functional Genomics Laboratory (The Dana Farber Cancer Institute and Harvard School of Public Health, Boston, MA; http://compbio.dfci.harvard.edu/tgi/) bovine gene index databases. The expression of genome-integrated exogenous human POU5F1, KLF4, SOX2, MYC, NANOG, LIN28, SV4OTAg, and hTERT (Table 2), and of the endogenous bovine orthologs, including POU5F1, KLF4, SOX2, MYC, NANOG, and LIN28 (Table 3), were examined.
The GoTaq system (Promega) was used subsequent to establishing the most efficient annealing and extension temperatures for trophectoderm-associated gene expression analysis. The trophectoderm-associated genes (Table 4) included ASCL2 (Achaete-scute complex homolog 2), CDX2 (Caudal-type homeobox protein 2), ELF5 (E74-like factor 5), ETS2 (v-Ets erythroblastosis virus E26 oncogene homolog 2), GATA2 (GATA binding protein 2), GATA3 (GATA binding protein 3), IFNT (Interferon-tau), SNF (Stratifin), and VIM (Vimentin). Also examined were ALB (albumin), ACTB (beta-actin; bovine specific), and GAPDH (glyceraldehyde-3-phosphate dehydrogenase; both mouse and bovine mRNAs). For each gene assayed, 25 ng RNA equivalents of the reverse-transcribed CDNA were used for PCR in a reaction mix containing $1 \mathrm{X}$ Platinum Taq PCR buffer (Life Technologies), $10 \mu \mathrm{M}$ gene-specific forward and reverse primers, $1.5 \mathrm{mM} \mathrm{MgCl}_{2}$, and $1 \mathrm{U}$ Platinum Taq (Life Technologies). PCR was carried out as follows: $95^{\circ} \mathrm{C}, 10 \mathrm{~min}$, followed by 35 cycles of $95^{\circ} \mathrm{C}$, $15 \mathrm{sec} ; 60^{\circ} \mathrm{C}, 15 \mathrm{sec}$; and $72^{\circ} \mathrm{C}, 15 \mathrm{sec}$. The amplicons (all about 100 base pairs) were resolved on a $3.5 \%$ polyacrylamide gel in $1 \mathrm{X}$ Tris ( $89 \mathrm{mM})$, borate $(89 \mathrm{mM})$, EDTA $(2 \mathrm{mM})$ buffer, $\mathrm{pH}$ 8.3. Gels were 
stained with ethidium bromide to visualize the amplicons with ultraviolet light.

\subsection{Transmission electron microscopy}

Transmission electron microscopy sample preparation and microscopy were performed with assistance of JFE Enterprises (Brookville, MD). T12.5 flasks were washed with phosphate-buffered saline, fixed for $1 \mathrm{hr}$ with $2.5 \%$ glutaraldehyde, and washed with and stored under Millonig's buffer at $4^{\circ} \mathrm{C}$. Cells were post-fixed with $1 \%$ osmium tetroxide, and stained with $2 \%$ uranyl acetate. Samples were dehydrated in ethanol, and placed in propylene oxide prior to embedding in Epon 812. Plastic sections were prepared and stained with lead citrate for examination with a Zeiss EM10 CA transmission electron microscope (Zeiss Corporation).

\section{ACKNOWLEDGMENTS}

The authors thank Dr. Bhanu P. Telugu for guidance in the design and preparation of reprogramming vectors. We also thank Ms. Amy Shannon and Mr. Paul Graninger for technical assistance in proteomic analysis, and Ms. Tammy Putmon for assistance with reverse-transcription PCR assays.

\section{FUNDING}

This research did not receive any specific grant from any funding agency in the public, commercial or not-for-profit sector.

\section{REFERENCES}

Adachi, K., Suemori, H., Yasuda, S. Y., Nakatsuji, N., \& Kawase, E. (2010). Role of SOX2 in maintaining pluripotency of human embryonic stem cells. Genes to Cells, 15, 455-470.

Avilion, A. A., Nicolis, S. K., Pevny, L. H., Perez, L., Vivian, N., \& Lovell-Badge, R. (2003). Multipotent cell lineages in early mouse development depend on SOX2 function. Genes \& Development, 17, 126-140.

Bai, H., Sakurai, T., Someya, Y., Konno, T., Ideta, A., Aoyagi, Y., \& Imakawa, K. (2011). Regulation of trophoblast-specific factors by GATA2 and GATA3 in bovine trophoblast CT-1 cells. Journal of Reproduction and Development, 57, 518-525.

Bao, L., He, L., Chen, J., Wu, Z., Liao, J., Rao, L., ... Xiao, L. (2011). Reprogramming of ovine adult fibroblasts to pluripotency via druginducible expression of defined factors. Cell Research, 21, 600-608.

Benchetrit, H., Herman, S., van Wietmarschen, N., Wu, T., Makedonski, K. Maoz, N., ... Buganim, Y. (2015). Extensive nuclear reprogramming underlies lineage conversion into functional trophoblast stem-like cells. Cell Stem Cell, 17, 543-556.

Berg, D. K., Smith, C. S., Pearton, D. J., Wells, D. N., Broadhurst, R., Donnison, M., \& Pfeffer, P. L. (2011). Trophectoderm lineage determination in cattle. Developmental Cell, 20, 244-255.

Bernardo, A. S., Faial, T., Gardner, L., Niakan, K. K., Ortmann, D., Senner C. E., ... Pedersen, R. A. (2011). BRACHYURY and CDX2 mediate BMP-induced differentiation of human and mouse pluripotent stem cells into embryonic and extraembryonic lineages. Cell Stem Cell, 9 , 144-155.

Betteridge, K. J., Eaglesome, M. D., Randall, G. C., \& Mitchell, D. (1980). Collection, description and transfer of embryos from cattle 10-16 days after oestrus. Journal of Reproduction and Fertility, 59, 205-216.
Brambrink, T., Foreman, R., Welstead, G. G., Lengner, C. J., Wernig, M., Suh, H., \& Jaenisch, R. (2008). Sequential expression of pluripotency markers during direct reprogramming of mouse somatic cells. Cell Stem Cell, 2, 151-159.

Cao, H., Yang, P., Pu, Y., Sun, X., Yin, H., Zhang, Y., ... Zhang, X. (2012). Characterization of bovine induced pluripotent stem cells by lentiviral transduction of reprogramming factor fusion proteins. International Journal of Biological Sciences, 8, 498-511.

Carey, T. S., Choi, I., Wilson, C. A., Floer, M., \& Knott, J. G. (2014). Transcriptional reprogramming and chromatin remodeling accompanies Oct4 and Nanog silencing in mouse trophoblast lineage. Stem Cells and Development, 23, 219-229.

Cendron, L., Berni, R., Folli, C., Ramazzina, I., Percudani, R., \& Zanotti, G. (2007). The structure of 2-oxo-4-hydroxy-4-carboxy-5-ureidoimidazoline decarboxylase provides insights into the mechanism of uric acid degradation. The Journal of Biological Chemistry, 282, 18182-18189.

Chen, L., Yabuuchi, A., Eminli, S., Takeuchi, A., Lu, C. W., Hochedlinger, K., \& Daley, G. Q. (2009). Cross-regulation of the Nanog and Cdx2 promoters. Cell Research, 19, 1052-1061.

Cravero, D., Martignani, E., Miretti, S., Accornero, P., Pauciullo, A., Sharma, R., ... Baratta, M. (2015). Generation of induced pluripotent stem cells from bovine epithelial cells and partial redirection toward a mammary phenotype in vitro. Cellular Reprogramming, 17, 211-220.

Degrelle, S. A., Campion, E., Cabau, C., Piumi, F., Reinaud, P., Richard, C., .. . Hue, I. (2005). Molecular evidence for a critical period in mural trophoblast development in bovine blastocysts. Developments in Biologicals, 288, 448-460.

Donnison, M., Beaton, A., Davey, H. W., Broadhurst, R., L'Huillier, P., \& Pfeffer, P. L. (2005). Loss of the extraembryonic ectoderm in Elf5 mutants leads to defects in embryonic patterning. Development, 132, 2299-22308.

du Puy, L., Lopes, S. M., Haagsman, H. P., \& Roelen, B. A. (2011). Analysis of co-expression of OCT4, NANOG and SOX2 in pluripotent cells of the porcine embryo, in vivo and in vitro. Theriogenology, 75, 513-526.

Efe, J. A., Hilcove, S., Kim, J., Zhou, H., Ouyang, K., Wang, G., ... Ding, S. (2011). Conversion of mouse fibroblasts into cardiomyocytes using a direct reprogramming strategy. Nature Cell Biology, 13, 215-222.

Erlebacher, A., Price, K. A., \& Glimcher, L. H. (2004). Maintenance of mouse trophoblast stem cell proliferation by TGF-beta/activin. Developments in Biologicals, 275, 158-169.

Ezashi, T., Matsuyama, H., Telugu, B. P., \& Roberts, R. M. (2011). Generation of colonies of induced trophoblast cells during standard reprogramming of porcine fibroblasts to induced pluripotent stem cells. Biology of Reproduction, 85, 779-787.

Ezashi, T., Telugu, B. P., Alexenko, A. P., Sachdev, S., Sinha, S., \& Roberts, R. M. (2009). Derivation of induced pluripotent stem cells from pig somatic cells. Proceedings of the National Academy of Sciences of the United States of America, 106, 10993-10998.

Farin, C. E., Imakawa, K., Hansen, T. R., McDonnell, J. J., Murphy, C. N., Farin, P. W., \& Roberts, R. M. (1990). Expression of trophoblastic interferon genes in sheep and cattle. Biology of Reproduction, 43, 210-218.

Fujii, T., Moriyasu, S., Hirayama, H., Hashizume, T., \& Sawai, K. (2010). Aberrant expression patterns of genes involved in segregation of inner cell mass and trophectoderm lineages in bovine embryos derived from somatic cell nuclear transfer. Cellular Reprogramming, 12, 617-625.

Fujii, T., Sakurai, N., Osaki, T., Iwagami, G., Hirayama, H., Minamihashi, A., ... Sawai, K. (2013). Changes in the expression patterns of the genes involved in the segregation and function of inner cell mass and 
trophectoderm lineages during porcine preimplantation development. Journal of Reproduction and Development, 59, 151-158.

Gafni, O., Weinberger, L., Mansour, A. A., Manor, Y. S., Chomsky, E., BenYosef, D., ... Hanna, J. H. (2013). Derivation of novel human ground state naive pluripotent stem cells. Nature, 504, 282-286.

Gao, Y., Hyttel, P., Jammes, H., Rasmussen, M. A., Oestrup, O., Beaujean, N., $\&$ Hall, V. (2011). Epigenetic regulation of gene expression in porcine epiblast, hypoblast, trophectoderm and epiblast-derived neural progenitor cells. Epigenetics, 6, 1149-1161.

Goissis, M. D., \& Cibelli, J. B. (2014). Functional characterization of CDX2 during bovine preimplantation development in vitro. Molecular Reproduction and Development, 81, 962-970.

Gossen, M., Freundlieb, S., Bender, G., Müller, G., Hillen, W., \& Bujard, H. (1995). Transcriptional activation by tetracyclines in mammalian cells. Science, 268, 1766-1769.

Guillemot, F., Nagy, A., Auerbach, A., Rossant, J., \& Joyner, A. L. (1994). Essential role of Mash-2 in extraembryonic development. Nature, 371, 333-336.

Han, X., Han, J., Ding, F., Cao, S., Lim, S. S., Dai, Y., ... Li, N. (2011). Generation of induced pluripotent stem cells from bovine embryonic fibroblast cells. Cell Research, 21, 1509-1512.

Heo, Y. T., Quan, X., Xu, Y. N., Baek, S., Choi, H., Kim, N. H., \& Kim, J. (2015). CRISPR/Cas9 nuclease-mediated gene knock-in in bovine-induced pluripotent cells. Stem Cells and Development, 24, 393-402.

Home, P., Ray, S., Dutta, D., Bronshteyn, I., Larson, M., \& Paul, S. (2009). GATA3 is selectively expressed in the trophectoderm of periimplantation embryo and directly regulates $\mathrm{Cdx} 2$ gene expression. The Journal of Biological Chemistry, 284, 28729-28737.

Huangfu, D., Maehr, R., Guo, W., Eijkelenboom, A., Snitow, M., Chen, A. E., \& Melton, D. A. (2008). Induction of pluripotent stem cells by defined factors is greatly improved by small-molecule compounds. Nature Biotechnology, 26, 795-797.

Hyslop, L., Stojkovic, M., Armstrong, L., Walter, T., Stojkovic, P., Przyborski, S., ... Lako, M. (2005). Downregulation of NANOG induces differentiation of human embryonic stem cells to extraembryonic lineages. Stem Cells, 23, 1035-1043.

Ivanova, N., Dobrin, R., Lu, R., Kotenko, I., Levorse, J., DeCoste, C., ... Lemischka, I. R. (2006). Dissecting self-renewal in stem cells with RNA interference. Nature, 442, 533-538.

Kawaguchi, T., Tsukiyama, T., Kimura, K., Matsuyama, S., Minami, N., Yamada, M., \& Imai, H. (2015). Generation of naïve bovine induced pluripotent stem cells using piggybac transposition of doxycyclineinducible transcription factors. PLoS ONE, 10, e0135403.

Keramari, M., Razavi, J., Ingman, K. A., Patsch, C., Edenhofer, F., Ward, C. M., \& Kimber, S. J. (2010). Sox2 is essential for formation of trophectoderm in the preimplantation embryo. PLOS ONE, 5, e13952.

Kim, J., Efe, J. A., Zhu, S., Talantova, M., Yuan, X., Wang, S., ... Ding, S. (2011). Direct reprogramming of mouse fibroblasts to neural progenitors. Proceedings of the National Academy of Sciences of the United States of America, 108, 7838-7843.

Kopp, J. L., Ormsbee, B. D., Desler, M., \& Rizzino, A. (2008). Small increases in the level of Sox 2 trigger the differentiation of mouse embryonic stem cells. Stem Cells, 26, 903-911.

Kubaczka, C., Senner, C. E., Cierlitza, M., Araúzo-Bravo, M. J., Kuckenberg, P., Peitz, M., ... Schorle, H. (2015). Direct Induction of trophoblast stem cells from murine fibroblasts. Cell Stem Cell, 17, 557-568.

Kuckenberg, P., Peitz, M., Kubaczka, C., Becker, A., Egert, A., Wardelmann, E., .. S Schorle, H. (2011). Lineage conversion of murine extraembryonic trophoblast stem cells to pluripotent stem cells. Molecular and Cellular Biology, 31, 1748-1756.
Kuijk, E. W., Du Puy, L., Van Tol, H. T., Oei, C. H., Haagsman, H. P., Colenbrander, B., \& Roelen, B. A. (2008). Differences in early lineage segregation between mammals. Developmental Dynamics, 237, 918-927.

Kwiecińska, P., Wiśniewska, J., \& Gregoraszczuk, E. (2011). Effects of valproic acid (VPA) and levetiracetam (LEV) on proliferation, apoptosis and hormone secretion of the human choriocarcinoma BeWo cell line. Pharmacological Reports, 63, 1195-1202.

Lee, K. L., Lim, S. K., Orlov, Y. L., Yit le, Y., Yang, H., Ang, L. T., Poellinger, L., \& Lim, B. (2011). Graded Nodal/Activin signaling titrates conversion of quantitative phospho-Smad2 levels into qualitative embryonic stem cell fate decisions. PLoS Genetics, 7, e1002130.

Li, J., Pan, G., Cui, K., Liu, Y., Xu, S., \& Pei, D. (2007). A dominant-negative form of mouse SOX2 induces trophectoderm differentiation and progressive polyploidy in mouse embryonic stem cells. The Journal of Biological Chemistry, 282, 19481-19492.

Li, Y., Cang, M., Lee, A. S., Zhang, K., \& Liu, D. (2011). Reprogramming of sheep fibroblasts into pluripotency under a drug-inducible expression of mouse-derived defined factors. PLOS ONE, 6, e15947.

Li, Y., Moretto-Zita, M., Soncin, F., Wakeland, A., Wolfe, L., Leon-Garcia, S., ... Parast, M. M. (2013). BMP4-directed trophoblast differentiation of human embryonic stem cells is mediated through a $\Delta \mathrm{Np63+}$ cytotrophoblast stem cell state. Development, 140, 3965-3976.

Lin, S. C., Wani, M. A., Whitsett, J. A., \& Wells, J. M. (2010). KIf5 regulates lineage formation in the pre-implantation mouse embryo. Development, 137, 3953-3963.

Lu, C. W., Yabuuchi, A., Chen, L., Viswanathan, S., Kim, K., \& Daley, G. Q. (2008). Ras-MAPK signaling promotes trophectoderm formation from embryonic stem cells and mouse embryos. Nature Genetics, 40, 921-926.

Madeja, Z. E., Sosnowski, J., Hryniewicz, K., Warzych, E., Pawlak, P., Rozwadowska, N., ... Lechniak, D. (2013). Changes in sub-cellular localisation of trophoblast and inner cell mass specific transcription factors during bovine preimplantation development. BMC Developmental Biology, 13, 32.

Margariti, A., Winkler, B., Karamariti, E., Zampetaki, A., Tsai, T. N., Baban, D., ... Xu, Q. (2012). Direct reprogramming of fibroblasts into endothelial cells capable of angiogenesis and reendothelialization in tissueengineered vessels. Proceedings of the National Academy of Sciences of the United States of America, 109, 13793-13798.

Maruotti, J., Muñoz, M., Degrelle, S. A., Gómez, E., Louet, C., Díez, C., ... Jouneau, A. (2012). Efficient derivation of bovine embryonic stem cells needs more than active core pluripotency factors. Molecular Reproduction and Development, 79, 461-477.

Mikkelsen, T. S., Hanna, J., Zhang, X., Ku, M., Wernig, M., Schorderet, P., ... Meissner, A. (2008). Dissecting direct reprogramming through integrative genomic analysis. Nature, 454, 49-55.

Nagy, K., Sung, H. K., Zhang, P., Laflamme, S., Vincent, P., AghaMohammadi, S., ... Nagy, A. (2011). Induced pluripotent stem cell lines derived from equine fibroblasts. Stem Cell Reviews, 7, 693-702.

Ng, R. K., Dean, W., Dawson, C., Lucifero, D., Madeja, Z., Reik, W., \& Hemberger, M. (2008). Epigenetic restriction of embryonic cell lineage fate by methylation of Elf5. Nature Cell Biology, 10, 1280-1290.

Niakan, K. K., \& Eggan, K. (2013). Analysis of human embryos from zygote to blastocyst reveals distinct gene expression patterns relative to the mouse. Developments in Biologicals, 375, 54-64.

Nichols, J., Zevnik, B., Anastassiadis, K., Niwa, H., Klewe-Nebenius, D., Chambers, I., ... Smith, A. (1998). Formation of pluripotent stem cells in the mammalian embryo depends on the POU transcription factor Oct4. Cell, 95, 379-391. 
Nicolas, J. F., Avner, P., Gaillard, J., Guenet, J. L., Jakob, H., \& Jacob, F. (1976). Cell lines derived from teratocarcinomas. Cancer Research, 36, 4224-4231.

Niwa, H., Miyazaki, J., \& Smith, A. G. (2000). Quantitative expression of Oct-3/4 defines differentiation, dedifferentiation or self-renewal of ES cells. Nature Genetics, 24, 372-376.

Niwa, H., Toyooka, Y., Shimosato, D., Strumpf, D., Takahashi, K., Yagi, R., \& Rossant, J. (2005). Interaction between Oct3/4 and Cdx2 determines trophectoderm differentiation. Cell, 123, 917-929.

Nong, W., Xie, T. S., Li, L. Y., Lu, A. G., Mo, J., Gou, Y. F., .. Huang, B. (2015). Qualitative analyses of protein phosphorylation in bovine pluripotent stem cells generated from embryonic fibroblasts. Reproduction in Domestic Animals, 50, 989-998.

Okita, K., Ichisaka, T., \& Yamanaka, S. (2007). Generation of germline competent induced pluripotent stem cells. Nature, 448, 313-317.

Ozawa, M., Sakatani, M., Yao, J., Shanker, S., Yu, F., Yamashita, R., ... Hansen, P. J. (2012). Global gene expression of the inner cell mass and trophectoderm of the bovine blastocyst. BMC Developmental Biology, 12, 33.

Pearton, D. J., Broadhurst, R., Donnison, M., \& Pfeffer, P. L. (2011). Elf5 regulation in the trophectoderm. Developments in Biologicals, 360, 343-350.

Pfeffer, P. L., \& Pearton, D. J. (2012). Trophoblast development. Reproduction, 143, 231-246.

Polo, J. M., Liu, S., Figueroa, M. E., Kulalert, W., Eminli, S., Tan, K. Y., .. Hochedlinger, K. (2010). Cell type of origin influences the molecular and functional properties of mouse induced pluripotent stem cells. Nature Biotechnology, 28, 848-855.

Powell, A. M., Talbot, N. C., Wells, K. D., Kerr, D. E., Pursel, V. G., \& Wall, R. J. (2004). Cell donor influences success of producing cattle by somatic cell nuclear transfer. Biology of Reproduction, 71, 210-216.

Pu, H. H., Duan, J., Wang, Y., Fan, D. X., Li, D. J., \& Jin, L. P. (2012). Thymic stromal lymphopoietin promotes the proliferation of human trophoblasts via phosphorylated STAT3-mediated c-Myc upregulation. Placenta, 33, 387-391.

Ren, J., Pak, Y., He, L., Qian, L., Gu, Y., Li, H., . . Xiao, L. (2011). Generation of hircine-induced pluripotent stem cells by somatic cell reprogramming. Cell Research, 21, 849-853.

Roberts, R. M., Imakawa, K., Niwano, Y., Kazemi, M., Malathy, P. V., Hansen, T. R., ... Kronenbert, L. H. (1989). Interferon production by the preimplanation sheep embryo. Journal of Interferon Research, 9, 175-187.

Rydnert, J., Pfeifer-Ohlsson, S., Goustin, A. S., \& Ohlsson, R. (1987) Temporal and spatial pattern of cellular myc oncogene expression during human placental development. Placenta, 8, 339-345.

Sakurai, T., Bai, H., Bai, R., Arai, M., Iwazawa, M., Zhang, J., . . Imakawa, K. (2012). Coculture system that mimics in vivo attachment processes in bovine trophoblast cells. Biology of Reproduction, 87, 1-11.

Sandmaier, S. E., Nandal, A., Powell, A., Garrett, W., Blomberg, L., Donovan, D. M., ... Telugu, B. P. (2015). Generation of induced pluripotent stem cells from domestic goats. Molecular Reproduction and Development, 82, 709-721.

Schiffmacher, A. T., \& Keefer, C. L. (2013). CDX2 regulates multiple trophoblast genes in bovine trophectoderm CT-1 cells. Molecular Reproduction and Development, 80, 826-839.

Schulz, L. C., Ezashi, T., Das, P., Westfall, S. D., Livingston, K. A., \& Roberts, R. M. (2008). Human embryonic stem cells as models for trophoblast differentiation. Placenta, 29(Suppl A), S10-S16.

Seabrook, J. L., Cantlon, J. D., Cooney, A. J., McWhorter, E. E., Fromme, B. A., Bouma, G. J., ... Winger, Q. A. (2013). Role of LIN28A in mouse and human trophoblast cell differentiation. Biology of Reproduction, 89, 1-13.

Segre, J. A., Bauer, C., \& Fuchs, E. (1999). Klf4 is a transcription factor required for establishing the barrier function of the skin. Nature Genetics, 22, 356-360.

Silva, J., Barrandon, O., Nichols, J., Kawaguchi, J., Theunissen, T. W., \& Smith, A. (2008). Promotion of reprogramming to ground state pluripotency by signal inhibition. PLoS Biology, 6, e253.

Song, H., Li, H., Huang, M., Xu, D., Gu, C., Wang, Z., ... Wang, F. (2013). Induced pluripotent stem cells from goat fibroblasts. Molecular Reproduction and Development, 80, 1009-1017.

Sritanaudomchai, H., Sparman, M., Tachibana, M., Clepper, L., Woodward, J., Gokhale, S., ... Mitalipov, S. (2009). CDX2 in the formation of the trophectoderm lineage in primate embryos. Developments in Biologicals, 335, 179-187.

Strumpf, D., Mao, C. A., Yamanaka, Y., Ralston, A., Chawengsaksophak, K., Beck, F., \& Rossant, J. (2005). Cdx2 is required for correct cell fate specification and differentiation of trophectoderm in the mouse blastocyst. Development, 132, 2093-2102.

Suasnavas, E. A., Heywood, S., Ward, A., Cox, L., O'Grady, M., Zhao, Y., ... Isom, S. C. (2015). Isolation and characterization of trophoblast-derived stem-like cells from peri-implantation porcine embryos. Animal Reproduction Science, 154, 128-141.

Sumer, H., Liu, J., Malaver-Ortega, L. F., Lim, M. L., Khodadadi, K., \& Verma, P. J. (2011). NANOG is a key factor for induction of pluripotency in bovine adult fibroblasts. Journal of Animal Science, 89, 2708-2716.

Sumi, T., Tsuneyoshi, N., Nakatsuji, N., \& Suemori, H. (2007). Apoptosis and differentiation of human embryonic stem cells induced by sustained activation of c-Myc. Oncogene, 26, 5564-5576.

Takahashi, K., Tanabe, K., Ohnuki, M., Narita, M., Ichisaka, T., Tomoda, K., \& Yamanaka, S. (2007). Induction of pluripotent stem cells from adult human fibroblasts by defined factors. Cell, 131, 861-872.

Takahashi, K., \& Yamanaka, S. (2006). Induction of pluripotent stem cells from mouse embryonic and adult fibroblast cultures by defined factors. Cell, 126, 663-676.

Talbot, N. C., Caperna, T. J., Edwards, J. L., Garrett, W., Wells, K. D., \& Ealy, A. D. (2000). Establishment of bovine blastocyst-derived trophectoderm and endoderm cell lines: Use of interferon-tau and serum protein expression as respective in vitro markers. Biology of Reproduction, 62, 235-247.

Talbot, N. C., Caperna, T. J., Powell, A. M., Garrett, W. M., \& Ealy, A. D. (2004). Isolation and characterization of a bovine trophectoderm cell line derived from a parthenogenetic blastocyst. Molecular Reproduction and Development, 69, 164-173.

Talbot, N. C., Powell, A. M., Camp, M., \& Ealy, A. D. (2007). Establishment of a bovine blastocyst-derived cell line collection for the comparative analysis of embryos created in vivo and by in vitro fertilization, somatic cell nuclear transfer, or parthenogenetic activation. In Vitro Cellular and Developmental Biology Animal Developmental Biology, 43, 59-71.

Talbot, N. C., Powell, A. M., Caperna, T. J., \& Garrett, W. M. (2010). Proteomic analysis of the major cellular proteins of bovine trophectoderm cell lines derived from IVP, parthenogenetic and nuclear transfer embryos: Reduced expression of annexins I and II in nuclear transferderived cell lines. Animal Reproduction Science, 120, 187-202.

Talbot, N. C., Powell, A. M., \& Garrett, W. M. (2002). Spontaneous differentiation of porcine and bovine embryonic stem cells (epiblast) into astrocytes or neurons. In Vitro Cellular and Developmental Biology Animal Developmental Biology, 38, 191-197.

Talbot, N. C., Powell, A. M., \& Rexroad, C. E., Jr. (1995). In vitro pluripotency of epiblasts derived from bovine blastocysts. Molecular Reproduction and Development, 42, 35-52. 
Talbot, N. C., Rexroad, C. E., Jr, Pursel, V. G., \& Powell, A. M. (1993). Alkaline phosphatase staining of pig and sheep epiblast cells in culture. Molecular Reproduction and Development, 36, 139-147.

Talbot, N. C., Sparks, W. O., Powell, A. M., Kahl, S., \& Caperna, T. J. (2012). Quantitative and semiquantitative immunoassay of growth factors and cytokines in the conditioned medium of STO and CF-1 mouse feeder cells. In Vitro Cellular and Developmental Biology Animal Developmental Biology, 48, 1-11.

Talluri, T. R., Kumar, D., Glage, S., Garrels, W., Ivics, Z., Debowski, K., ... Kues, W. A. (2015). Derivation and characterization of bovine induced pluripotent stem cells by transposon-mediated reprogramming. Cellular Reprogramming, 17, 131-140.

Tanaka, S., Kunath, T., Hadjantonakis, A. K., Nagy, A., \& Rossant, J. (1998). Promotion of trophoblast stem cell proliferation by FGF4. Science, 282, 2072-2075.

Telugu, B. P., Ezashi, T., \& Roberts, R. M. (2010). Porcine induced pluripotent stem cells analogous to naïve and primed embryonic stem cells of the mouse. International Journal of Developmental Biology, 54, 1703-1711.

Telugu, B. P., Ezashi, T., Sinha, S., Alexenko, A. P., Spate, L., Prather, R. S., \& Roberts, R. M. (2011). Leukemia inhibitory factor (LIF)-dependent, pluripotent stem cells established from inner cell mass of porcine embryos. The Journal of Biological Chemistry, 286, 28948-28953.

Tetens, F., Kliem, A., Tscheudschilsuren, G., Navarrete Santos, A., \& Fischer, B. (2000). Expression of proto-oncogenes in bovine preimplantation blastocysts. Anatomy and Embryology, 201, 349-355.

Thier, M., Wörsdörfer, P., Lakes, Y. B., Gorris, R., Herms, S., Opitz, T., .. . Edenhofer, F. (2012). Direct conversion of fibroblasts into stably expandable neural stem cells. Cell Stem Cell, 10, 473-479.

Thomson, A. J., Pierart, H., Meek, S., Bogerman, A., Sutherland, L., Murray, H., \& Burdon, T. . . (2012). Reprogramming pig fetal fibroblasts reveals a functional LIF signaling pathway. Cellular Reprogramming, 14, 112-122.

Vogt, E. J., Meglicki, M., Hartung, K. I., Borsuk, E., \& Behr, R. (2012). Importance of the pluripotency factor LIN28 in the mammalian nucleolus during early embryonic development. Development, 139, 4514-4523.

Wernig, M., Meissner, A., Foreman, R., Brambrink, T., Ku, M., Hochedlinger, K., ... Jaenisch, R. (2007). In vitro reprogramming of fibroblasts into a pluripotent ES cell-like state. Nature, 448, 318-324.

West, F. D., Terlouw, S. L., Kwon, D. J., Mumaw, J. L., Dhara, S. K., Hasneen, K., ... Stice, S. L. (2010). Porcine induced pluripotent stem cells produce chimeric offspring. Stem Cells and Development, 19, 1211-1220.
West, F. D., Uhl, E. W., Liu, Y., Stowe, H., Lu, Y., Yu, P., .. Stice, S. L. (2011). Brief report: Chimeric pigs produced from induced pluripotent stem cells demonstrate germline transmission and no evidence of tumor formation in young pigs. Stem Cells, 29, 1640-1643.

White, L. J., Declercq, W., Arfuso, F., Charles, A. K., \& Dharmarajan, A. M. (2009). Function of caspase-14 in trophoblast differentiation. Reproductive Biology and Endocrinology, 7, 98.

Wobus, A. M., Holzhausen, H., Jäkel, P., \& Schöneich, J. (1984). Characterization of a pluripotent stem cell line derived from a mouse embryo. Experimental Cell Research, 152, 212-219.

Wu, Z., Chen, J., Ren, J., Bao, L., Liao, J., Cui, C., ... Xiao, L. (2009). Generation of pig induced pluripotent stem cells with a drug-inducible system. Journal of Molecular Cell Biology, 1, 46-54.

Wu, T., Wang, H., He, J., Kang, L., Jiang, Y., Liu, J., ... Gao, S. (2011). Reprogramming of trophoblast stem cells into pluripotent stem cells by Oct4. Stem Cells, 29, 755-763.

Xu, R. H., Chen, X., Li, D. S., Li, R., Addicks, G. C., Glennon, C., .. Thomson, J. A. (2002). BMP4 initiates human embryonic stem cell differentiation to trophoblast. Nature Biotechnology, 20, 1261-1264.

Yang, D. H., \& Moss, E. G. (2003). Temporally regulated expression of Lin-28 in diverse tissues of the developing mouse. Gene Expression Patterns, 3, 719-726.

Ying, Q. L., Wray, J., Nichols, J., Batlle-Morera, L., Doble, B., Woodgett, J., ... Smith, A. (2008). The ground state of embryonic stem cell selfrenewal. Nature, 453, 519-523.

Yu, J., Vodyanik, M. A., Smuga-Otto, K., Antosiewicz-Bourget, J., Frane, J. L., Tian, S., ... Thomson, J. A. (2007). Induced pluripotent stem cell lines derived from human somatic cells. Science, 318, 1917-1920.

\section{SUPPORTING INFORMATION}

Additional Supporting Information may be found online in the supporting information tab for this article.

How to cite this article: Talbot NC, Sparks WO, Phillips CE, et al. Bovine trophectoderm cells induced from bovine fibroblasts with induced pluripotent stem cell reprogramming factors. Mol Reprod Dev. 2017;84:468-485. https://doi.org/10.1002/mrd.22797 